Florida International University FIU Digital Commons

$7-1-2013$

\title{
Buckwheat as a Cover Crop in Florida: Mycorrhizal Status, Soil Analysis, and Economic Assessment
}

Daria Boglaienko

dbog1003@fiu.edu

DOI: $10.25148 /$ etd.FI13080711

Follow this and additional works at: https:// digitalcommons.fiu.edu/etd

Part of the Agricultural Science Commons, Agronomy and Crop Sciences Commons, and the Environmental Health Commons

\section{Recommended Citation}

Boglaienko, Daria, "Buckwheat as a Cover Crop in Florida: Mycorrhizal Status, Soil Analysis, and Economic Assessment" (2013). FIU Electronic Theses and Dissertations. 921.

https://digitalcommons.fiu.edu/etd/921 


\title{
FLORIDA INTERNATIONAL UNIVERSITY
}

Miami, Florida

\section{BUCKWHEAT AS A COVER CROP IN FLORIDA: MYCORRHIZAL STATUS, SOIL ANALYSIS, AND ECONOMIC ASSESSMENT}

\author{
A thesis submitted in partial fulfillment of the \\ requirements for the degree of \\ MASTER OF SCIENCE \\ in \\ ENVIRONMENTAL STUDIES \\ by
}

Daria Boglaienko

2013 
To: Dean Kenneth G. Furton

College of Arts and Sciences

This thesis, written by Daria Boglaienko, and entitled Buckwheat as a Cover Crop in Florida: Mycorrhizal Status, Soil Analysis, and Economic Assessment, having been approved in respect to style and intellectual content, is referred to you for judgment.

We have read this thesis and recommend that it be approved.

Mahadev Bhat

Kateel Shetty

Krishnaswamy Jayachandran, Major Professor

Date of Defense: July 1, 2013

The thesis of Daria Boglaienko is approved.

$\begin{array}{r}\text { Dean Kenneth G. Furton } \\ \text { College of Arts and Sciences } \\ \hline \begin{array}{r}\text { Dean Lakshmi N. Reddi } \\ \text { University Graduate School }\end{array}\end{array}$

Florida International University, 2013 


\section{DEDICATION}

I dedicate this thesis to my family in Ukraine, my grandmother, mother and sister. 


\author{
ABSTRACT OF THESIS \\ BUCKWHEAT AS A COVER CROP IN FLORIDA: MYCORRHIZAL STATUS, SOIL \\ ANALYSIS, AND \\ ECONOMIC ASSESSMENT \\ by
}

Daria Boglaienko

Florida International University, 2013

Miami, Florida

Professor Krishnaswamy Jayachandran, Major Professor

This thesis analyses buckwheat as a cover crop in Florida. The study was designed to demonstrate: soil enrichment with nutrients, mycorrhizal arbuscular fungi interactions, growth in different soil types, temperature limitations in Florida, and economic benefits for farmers. Buckwheat was planted at the FIU organic garden (Miami, FL) in early November and harvested in middle December. After incorporation of buckwheat residue, soil analyses indicated the ability of buckwheat to enrich soil with major nutrients, in particular, phosphorus. Symbiosis with arbuscular mycorrhizal fungi increased inorganic phosphorus uptake and plant growth. Regression analysis on aboveground buckwheat biomass weight and soil characteristics showed that high soil $\mathrm{pH}$ was the major limiting factor that affected buckwheat growth. Spatial analysis illustrated that buckwheat could be planted in South Florida throughout the year but might not be planted in North and Central Florida in winter. An economic assessment proved buckwheat to be a profitable cover crop. 


\section{TABLE OF CONTENTS}

CHAPTER

PAGE

INTRODUCTION ..........................................................

CHAPTER 1. LITERATURE REVIEW.................................... 3

CHAPTER 2. EXPERIMENT 1. GROWTH CHAMBER STUDY:

MYCORRHIZAL COLONIZATION IN FAGOPYRUM ESCULENTUM ..........15

2.1. Introduction................................................. 15

2.2. Materials and Methods........................................... 16

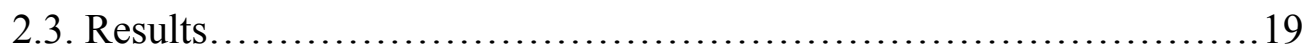

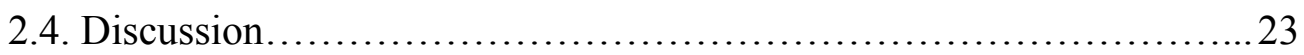

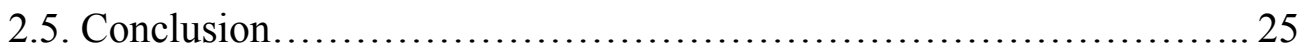

CHAPTER 3. EXPERIMENT 2. ORGANIC GARDEN: BUCKWHEAT AS

A COVER CROP .................................................................. 26

3.1. Introduction.................................................... 26

3.2. Materials and Methods ......................................... 26

3.3. Results............................................................ 30

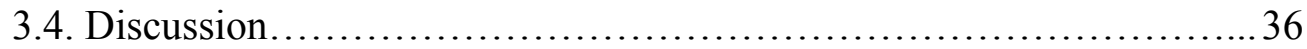

3.5. Conclusion.................................................... 38

CHAPTER 4. EXPERIMENT 3. RESPONSE TO DIFFERENT SOIL TYPES... 39

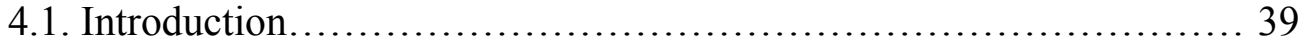

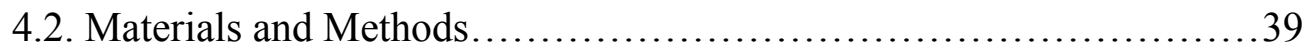

4.3. Results......................................................... 40

4.4. Discussion............................................................ 44

4.5. Conclusion...................................................... 45

CHAPTER 5. SPATIAL ANALYSIS OF BUCKWHEAT FOR POTENTIAL

USE AS A COVER CROP IN FLORIDA FARMS...............................46

5.1. Introduction................................................. 46

5.2. Materials and Methods ........................................ 46

5.3. Results.......................................................... 47

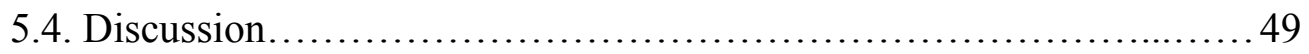

5.5. Conclusion.................................................. 50

CHAPTER 6. ECONOMIC ASSESSMENT ............................... 51

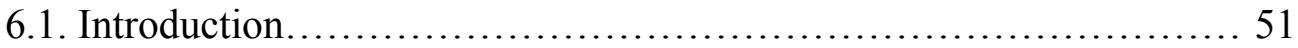

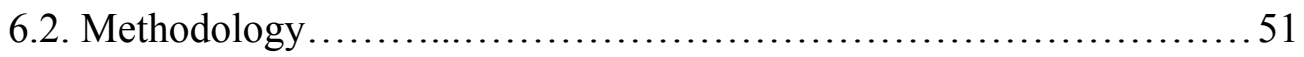

6.3. Calculations...................................................... 53

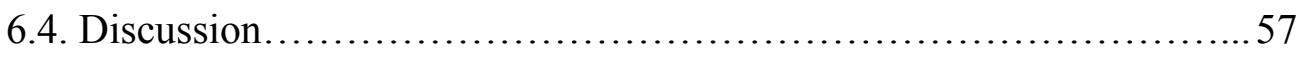

6.5. Conclusion.................................................... 58 


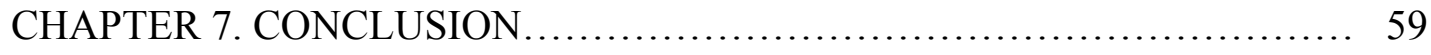

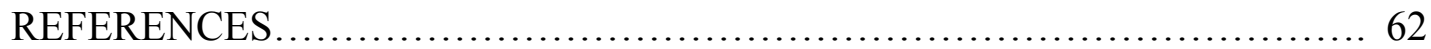




\section{LIST OF TABLES}

TABLE

PAGE

1.1. Nutritional comparison between most popular grain crops.................. 7

2.1. Treatment effect on buckwheat plants height, weight, leaf mass ratio, LMR, and root:shoot ratio, RSR (means per pot).............................20

2.2. Treatment effect on phosphorus $(\mathrm{P})$, nitrogen $(\mathrm{N})$, and carbon $(\mathrm{C})$ concentrations in buckwheat leaves and stems.

2.3. Treatment effect on phosphorus $(\mathrm{P})$, nitrogen $(\mathrm{N})$, and carbon $(\mathrm{C})$ uptake in buckwheat leaves and stems

2.4. Percent colonization of buckwheat plants with AMF grown in different substrates.

3.1. Changes in soil $\mathrm{pH}$, bulk density, $\mathrm{BD}$, soil organic matter, $\mathrm{SOM}$, total nitrogen, $\mathrm{TN}$, total carbon, $\mathrm{TC}$, and carbon-nitrogen ratio $(\mathrm{C} / \mathrm{N})$ before planting buckwheat (B) and after incorporation and decomposition of buckwheat residues $(\mathrm{A})$.

3.2. Changes in available phosphorus, AP, total phosphorus, TP, potassium, $\mathrm{K}$, calcium, $\mathrm{Ca}$, and magnesium, $\mathrm{Mg}$, before planting buckwheat (B) and after incorporation and decomposition of buckwheat residues (A)

4.1. Aboveground dry biomass weight, $g$, for buckwheat plants grown in different soil types

4.2. Soil characteristics.

4.3. Pearson correlation coefficients for the regression analysis of buckwheat biomass weight and soil characteristics.

5.1. Florida counties where buckwheat should not be grown in January, February, and December (indicated with ' $x$ ') because of low winter temperatures.....48-49

6.1. Cost-benefit analysis of buckwheat as a cover crop. 


\section{LIST OF FIGURES}

FIGURE

PAGE

1.1. Buckwheat's grains and flowers..................................... 3

1.2. Worldwide buckwheat production and changes over 10 years.............. 5

1.3. Worldwide buckwheat production and changes over 10 years................6

1.4. Nutritional comparison in mineral characteristics between buckwheat and cereals .......................................................... 8

1.5. Distribution map of Fagopurum esculentum in Florida...................... 13

1.6. Distribution of Fagopurum esculentum Moench in the US.................... 14

2.1. Buckwheat in the growth chamber ( 2 weeks old plants $) \ldots \ldots \ldots \ldots \ldots \ldots \ldots \ldots$

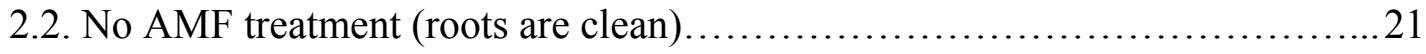

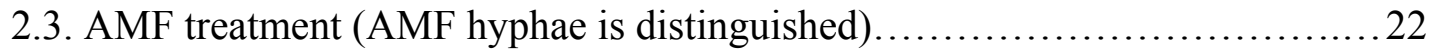

2.4. Mycorrhiza arbuscules and hyphae in buckwheat roots. The image 'Tree Tops Park' shows no inoculation........................................ 23

3.1. Buckwheat three weeks after the planting date.......................... 27

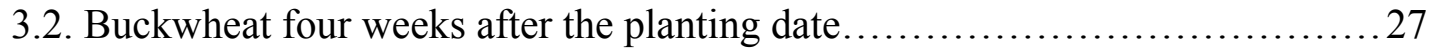

3.3. Buckwheat five weeks after the planting date.......................... 28

3.4. Buckwheat terminated (left) and four weeks after the termination (right)......28

3.5. Changes in soil $\mathrm{pH}$ in relation to depth................................ 31

3.6. Changes in soil bulk density in relation to depth........................ 31

3.7. Changes in soil organic matter (SOM) in relation to depth.................. 32

3.8. Changes in total nitrogen $(\mathrm{TN})$ in relation to depth...................... 32

3.9. Changes in total carbon (TC) in relation to depth........................ 33

3.10. Changes in available phosphorus (AP) in relation to depth................ 34 
3.11. Changes in total phosphorus (TP) in relation to depth.................... 34

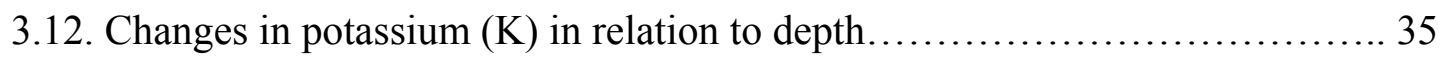

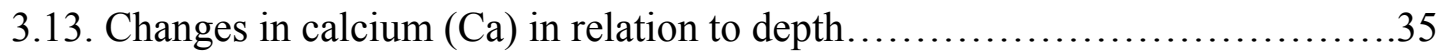

3.14. Changes in magnesium $(\mathrm{Mg})$ in relation to depth........................ 36

4.1. Relationship between soil organic matter, $\%$, and buckwheat biomass

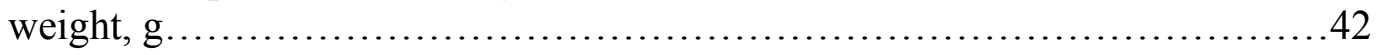

4.2. Relationship between soil bulk density, $\mathrm{g} / \mathrm{cm}^{3}$, and buckwheat biomass

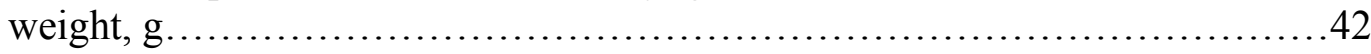

4.3. Relationship between texture ( $\%$ of sand) and buckwheat biomass

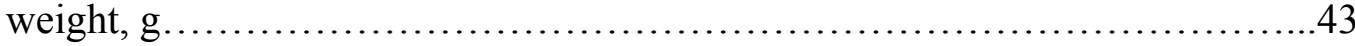

4.4. Relationship between $\mathrm{pH}$ and buckwheat biomass weight, $\mathrm{g} \ldots \ldots \ldots \ldots \ldots \ldots . . . .43$

5.1. Spatial analysis of the temperature regime for buckwheat growth in winter.... 50 


\section{INTRODUCTION}

"...he passed the fragrant buckwheat fields, breathing the odor of the beehive..."

Washington Irving. 'The Legend of Sleepy Hollow' (Irving, 2012, 1820).

Yet one and a half century ago buckwheat occupied more than a million acres in

the US. George Washington and Thomas Jefferson were two, the most famous, American farmers that grew buckwheat. Later, with specialization of agriculture, other cereal crops became major commodities in the United States and buckwheat was not among them (Buckwheat, n.d.).

Currently, a monoculture strategy prevails and the food market is dominated by few main cash crops. Diversification of the agricultural commodities on conventional farms has been proven to be beneficial not only for the human health but for ecosystems as well.

It is well known that conventional agriculture is not sustainable and causes numerous environmental problems including the most popular, the climate change (Gliessman, 2006). One such problem is the unbalanced use of fertilizers. Phosphorus, one of the main macronutrients for plants, applied as a fertilizer, arrives in water bodies with the surface runoff. Its nutrient loading causes algae blooms and low dissolved oxygen levels (Anderson et al., 2002). Moreover, phosphates mining sites are finite and are near the rate of exhaustion. Phosphorus is naturally present in soil as a mineral element in rocks (Ruttenberg, 2003). The question of how to make the 'earth' phosphorus more available for plant growth cycles and to prevent new 'mined' phosphate applications holds a prominent place on the agenda of the crop and soil science. 
Rotational systems utilize cover crops to return nutrients into soil with the incorporated organic residues and to control weeds in the following growing cycle. Buckwheat is well-known for its weed control and for returning phosphorus to soil.

There are several benefits from buckwheat farming. Chapter 1, 'Literature review', presents buckwheat's role as a cover crop and as a nutritious food source. Chapters 2, 3, and 4 address independent experiments that were designed to:

- understand the role of arbuscular mycorrhizal fungi symbiosis in phosphorus uptake by buckwheat, as well as fungal colonization impact on buckwheat growth rate;

- analyze buckwheat's ability to improve soil quality and enhance nutrient availability; and

- $\quad$ analyze dependence of buckwheat growth to particular soil by growing in different soil types that are common to Florida.

Chapter 5 is the spatial analysis that shows the potential to grow buckwheat in Florida during the year, considering the temperature limitations. Taking into account the fact that economics play one of the major roles in the crop choice, Chapter 6 , presents an economic assessment of the savings that a farmer would gain and also an evaluation of benefits to the agricultural ecosystem from growing buckwheat as a cover crop.

Thus, given study was aimed to prove buckwheat's benefits and suitability as a cover crop for Florida in terms of soil enrichment, possible climatic and soil limitations, and economic reasons. 


\section{CHAPTER 1}

\section{LITERATURE REVIEW}

Buckwheat - Fagopyrum esculentum Moench - is a pseudocereal; it belongs to Polygonaceae family that includes smartweed, sorrel, black bindweed, and dock. It is not a true cereal crop like oats, barley, or wheat, because it is a member of the Polygonaceae family but not the Poaceae family. It is a fast-growing, warm-season, broadleaf annual crop with small white or pink flowers (Sattel et al., 1998). The flower clusters develop into brown triangular seeds that consist of a groat surrounded by a thick hull (Myers \& Meinke, 1994), as shown in Figure 1.1. There are other commercially available species of buckwheat, such as $F$. tartaricum, $F$. sagittatum, $F$. emarginatum but the most common species is F. esculentum (Treadwel \& Huang, 2008; Zepp et al., 1996).

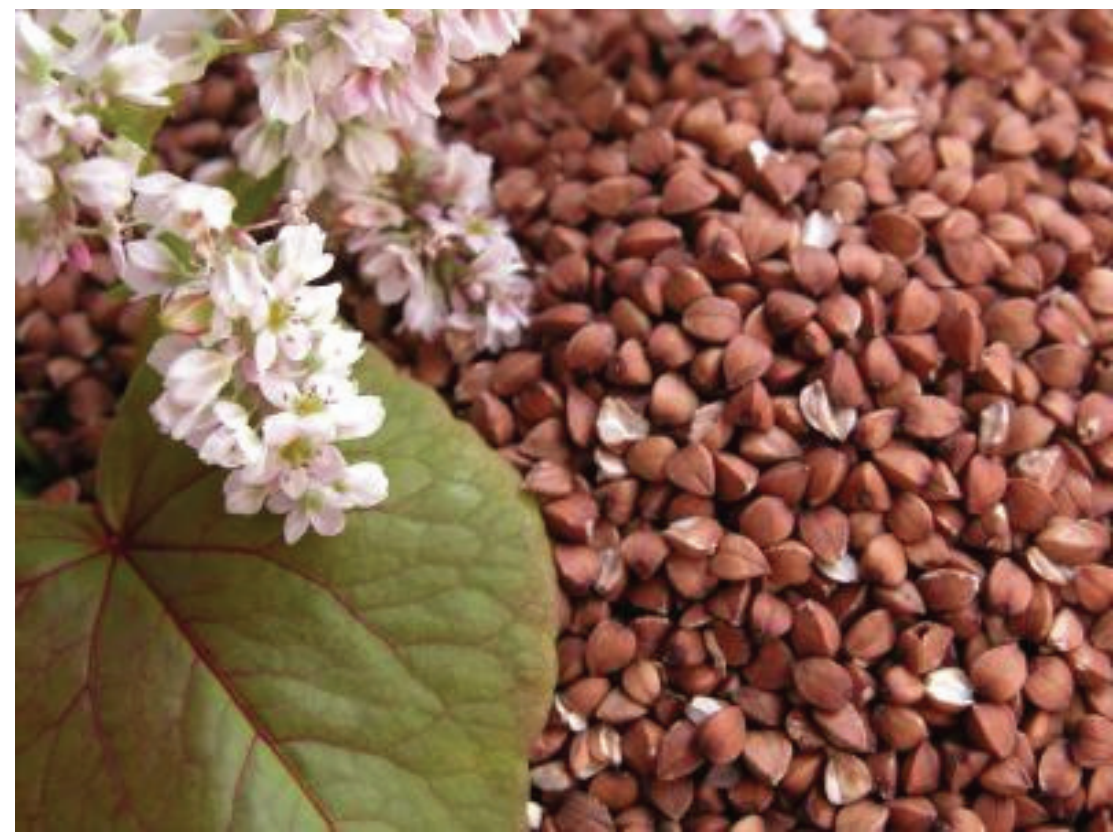

Figure 1.1. Buckwheat's grains and flowers.

Source: http://whatscookingamerica.net/CharlotteBradley/BuckwheatFlour.htm 
Buckwheat got its name from the fact that seeds are similar to the beech tree's seeds that are called boekweit in Dutch (Myers \& Meinke, 1994).

The origin of buckwheat is believed to be mountainous part of southwestern China. Buckwheat was one of the earliest domesticated crops and it was cultivated in China around 5000 years ago (Boland, 2013; Chen, 2001; Myers \& Meinke, 1994). It spread through Asia to Europe and the New World experienced the introduction of the crop in the 17th century with the movement of European colonists (Treadwell \& Huang, 2008). Buckwheat was popular in the US in the middle of the 19th century $(\sim 405,000 \mathrm{ha})$ as a forage crop and as a grain crop to make flour (Treadwell \& Huang, 2008). But later, in the $20^{\text {th }}$ century, with the green revolution and agricultural commodities specialization, its production declined 40 times and currently grown 10,020 ha (USDA NASS, 2007). In 2010, the US was the fifth largest buckwheat producer in the world (FAOSTAT, 2010), as demonstrated in Figure 1.2. Buckwheat is grown in northern states under a contract as a cash crop or as a food security crop in case wheat production fails. The states that grow buckwheat are North Dakota, Washington, Minnesota, New York, and Pennsylvania (Figure 1.3). A small percentage of this crop is grown for livestock feed, honey production, cover crop and weed control or for wildlife plantings (Zepp et al., 1996; Myers \& Meinke, 1994). Majority of the buckwheat is exported to Japan, where 'soba' noodles made of buckwheat are popular (Treadwell \& Huang, 2008). Thus, in 2012, Japan bought $96 \%$ of the US exported buckwheat (valued at \$14.1 million, Boland, 2013).

Figures 1.2 and 1.3 present global and US buckwheat production as a cash crop in 2010 (sq km). The main producers are China, Russia, and Ukraine. The map below show 
changes in harvested area from 1997 to 2007 . Red and orange colors indicate the countries where production had decreased. Green colors indicate increased buckwheat production (sq km).

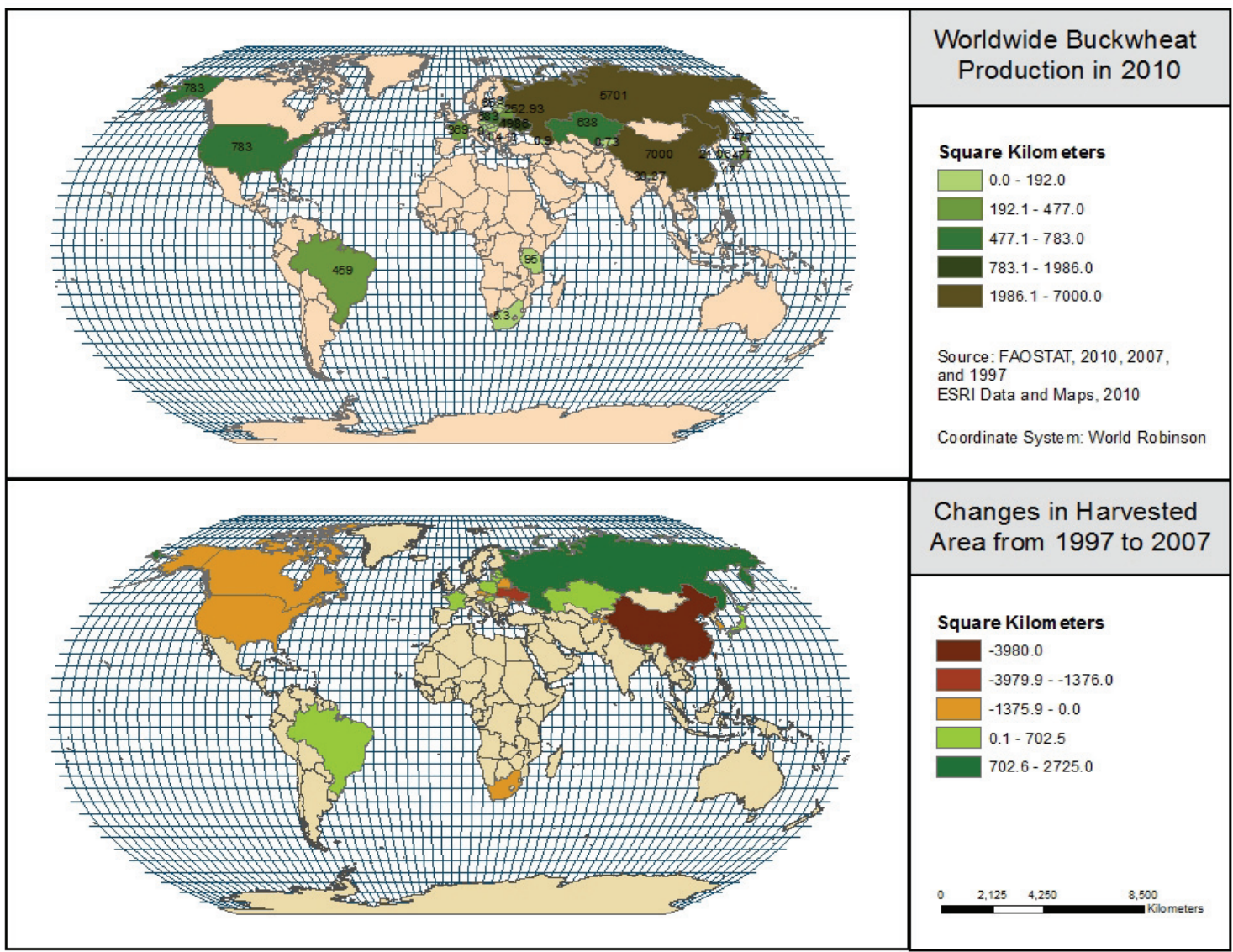

Daria Boglaienko, 2012

Figure 1.2. Worldwide buckwheat production and changes over 10 years.

As a food crop as well as a cash crop, it is one of the important crops in few countries such as Russia, China, Ukraine, Poland, and Japan (Parahin, 2010). In Russia, Ukraine, and few Eastern European countries it is utilized in a diet as a whole grain, boiled in water to make "kasha", and is considered to be beneficial for health. In Japan, except of soba noodles made of buckwheat flour, groats are utilized in breakfast foods 
and soups, and hulls are used as a filler for pillows (Zepp et al., 1996). Buckwheat tea is produced in China and buckwheat bread is popular in Slovenia. In France buckwheat is mainly grown for honey production. Beverage and ice cream industries also use buckwheat (Boland, 2013).

In the US buckwheat is not a cereal grain, however, dry and roasted grains could be found in the 'Whole Foods' stores or bought from the 'BirketMills' and 'Bob's Red Mill' companies. More often buckwheat could be found on the market shelves as flour in pancakes mixtures.
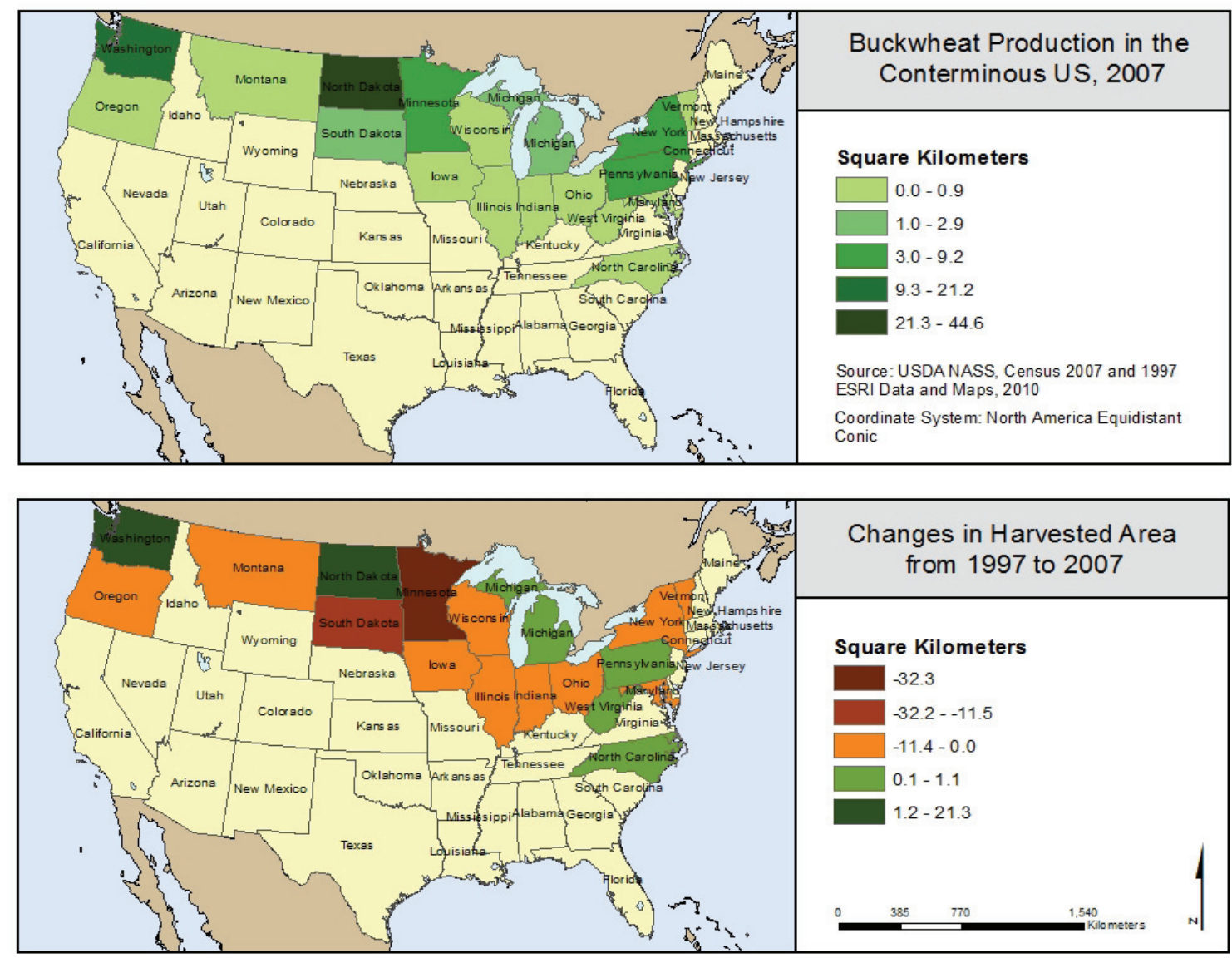

Daria Boglaienko, 2012

Figure 1.3. Worldwide buckwheat production and changes over 10 years. 
Table 1.1. Nutritional comparison between most popular grain crops. $f$

\begin{tabular}{|c|c|c|c|c|c|c|c|c|}
\hline & Buckwheat & Corn & Rye & Millet & Barley & Rice & Wheat & Oat \\
\hline $\begin{array}{l}\text { Protein } \\
\text { quality* }\end{array}$ & $\begin{array}{l}99 \\
13 \%\end{array}$ & $\begin{array}{l}55 \\
7 \%\end{array}$ & $\begin{array}{l}80 \\
13 \%\end{array}$ & $\begin{array}{l}37 \\
11 \%\end{array}$ & $\begin{array}{l}73 \\
7 \%\end{array}$ & $\begin{array}{l}75 \\
8 \%\end{array}$ & $\begin{array}{l}54 \\
15 \%\end{array}$ & $\begin{array}{l}81 \\
15 \%\end{array}$ \\
\hline $\begin{array}{l}\text { Minerals, g } \\
\mathrm{Ca} \\
\mathrm{Fe} \\
\mathrm{Mg} \\
\mathrm{P} \\
\mathrm{K} \\
\mathrm{Na} \\
\mathrm{Zn} \\
\mathrm{Cu} \\
\mathrm{Mn} \\
\mathrm{Se}, \mathrm{mcg}\end{array}$ & $\begin{array}{l}30.6 \\
3.7 \\
\mathbf{3 9 3} \\
590 \\
\mathbf{7 8 2} \\
1.7 \\
4.1 \\
\mathbf{1 . 9} \\
2.2 \\
14.1\end{array}$ & $\begin{array}{l}11.6 \\
4.5 \\
211 \\
349 \\
476 \\
\mathbf{5 8 . 1} \\
3.7 \\
0.5 \\
0.8 \\
25.7\end{array}$ & $\begin{array}{l}55.8 \\
4.5 \\
204 \\
632 \\
446 \\
10.1 \\
6.3 \\
0.8 \\
4.5 \\
59.7\end{array}$ & $\begin{array}{l}5.2 \\
1.1 \\
76.6 \\
174 \\
108 \\
3.5 \\
1.6 \\
0.3 \\
0.5 \\
1.6\end{array}$ & $\begin{array}{l}17.3 \\
2.1 \\
34.5 \\
84.8 \\
146 \\
4.7 \\
1.3 \\
0.2 \\
0.4 \\
13.5\end{array}$ & $\begin{array}{l}19.5 \\
0.8 \\
83.9 \\
162 \\
83.9 \\
9.8 \\
1.2 \\
0.2 \\
1 . .8 \\
19.1\end{array}$ & $\begin{array}{l}40.8 \\
4.7 \\
166 \\
415 \\
486 \\
6.0 \\
3.5 \\
0.5 \\
4.6 \\
\mathbf{8 4 . 8}\end{array}$ & $\begin{array}{l}\mathbf{8 4 . 3} \\
\mathbf{7 . 4} \\
276 \\
\mathbf{8 1 6} \\
669 \\
3.1 \\
6.2 \\
1.0 \\
\mathbf{7 . 7} \\
-\end{array}$ \\
\hline $\begin{array}{l}\text { Vitamins, g } \\
\text { A } \\
\text { C } \\
\text { D } \\
\text { E } \\
\text { K } \\
\text { Thiamin } \\
\text { Riboflavin } \\
\text { Niacin } \\
\text { B6 } \\
\text { Folate, mcg } \\
\text { B12, mcg } \\
\text { Pantothenic } \\
\text { Acid } \\
\text { Choline } \\
\text { Betaine }\end{array}$ & $\begin{array}{l}- \\
- \\
- \\
- \\
- \\
0.2 \\
\mathbf{0 . 7} \\
\mathbf{1 1 . 9} \\
0.4 \\
51.0 \\
- \\
2.1 \\
- \\
-\end{array}$ & $\begin{array}{l}\mathbf{3 5 5} \\
- \\
- \\
0.8 \\
0.5 \\
0.6 \\
0.3 \\
6.0 \\
\mathbf{1 . 0} \\
31.5 \\
- \\
0.7 \\
- \\
-\end{array}$ & $\begin{array}{l}18.6 \\
- \\
- \\
\mathbf{2 . 2} \\
\mathbf{1 0 . 0} \\
0.5 \\
0.4 \\
7.2 \\
0.5 \\
\mathbf{1 0 1} \\
- \\
\mathbf{2 . 5} \\
\mathbf{5 1 . 4} \\
-\end{array}$ & $\begin{array}{l}5.2 \\
- \\
- \\
- \\
0.5 \\
0.2 \\
0.1 \\
2.3 \\
0.2 \\
33.1 \\
- \\
0.3 \\
19.5 \\
-\end{array}$ & $\begin{array}{l}11.0 \\
- \\
- \\
- \\
1.3 \\
0.1 \\
0.1 \\
3.2 \\
0.2 \\
25.1 \\
- \\
0.2 \\
21.0 \\
-\end{array}$ & $\begin{array}{l}- \\
- \\
- \\
0.1 \\
1.2 \\
0.2 \\
- \\
3.0 \\
0.3 \\
7.8 \\
- \\
0.6 \\
17.9 \\
1.0\end{array}$ & $\begin{array}{l}10.8 \\
- \\
- \\
1.0 \\
2.3 \\
0.5 \\
0.3 \\
7.6 \\
0.4 \\
52.8 \\
- \\
1.2 \\
37.4 \\
\mathbf{8 7 . 4}\end{array}$ & $\begin{array}{l}- \\
- \\
- \\
- \\
- \\
\mathbf{1 . 2} \\
0.2 \\
1.5 \\
0.2 \\
87.4 \\
- \\
2.1 \\
- \\
-\end{array}$ \\
\hline $\begin{array}{l}\text { Dietary } \\
\text { fiber, } g\end{array}$ & 17.0 & 12.1 & 24.7 & 2.3 & 6.0 & 3.5 & 14.6 & 16.5 \\
\hline \multirow[t]{2}{*}{ Sugars, g } & - & 1.1 & 1.8 & 0.2 & 0.4 & 0.7 & 0.5 & - \\
\hline & Buckwheat & Corn & Rye & Millet & Barley & Rice & Wheat & Oat \\
\hline
\end{tabular}

* Protein quality is dependent on having all the essential amino acids in the proper proportions.

$t$ Data are taken from the source: http://nutritiondata.self.com/facts/cereal-grains-andpasta/5681/2\#ixzz2LN7XywqJ 
Buckwheat has a high nutritional value. The protein content is from 15-17 percent (Wang et al., 2010; Buckwheat, 2011). It contains 18 amino acids of the total 20 and importantly it is rich in the essential limiting amino acid lysine that is deficient in rice and wheat (Zepp et al., 1996; Treadwell \& Huang, 2008); its protein value is almost the same as that of a chicken egg. Buckwheat is a gluten free and it is the leading source of several minerals such as $\mathrm{Mg}, \mathrm{K}$, and $\mathrm{Cu}$, and vitamins niacin (B3) and riboflavin (B2) among all other grains (Parahin, 2010; Boland, 2013), Table 1.1. The researchers Ikeda et al. (2006) studied buckwheat in comparison with other cereals (wheat, rice, and corn). Mineral content for these crops is given on the Figure 1.4.

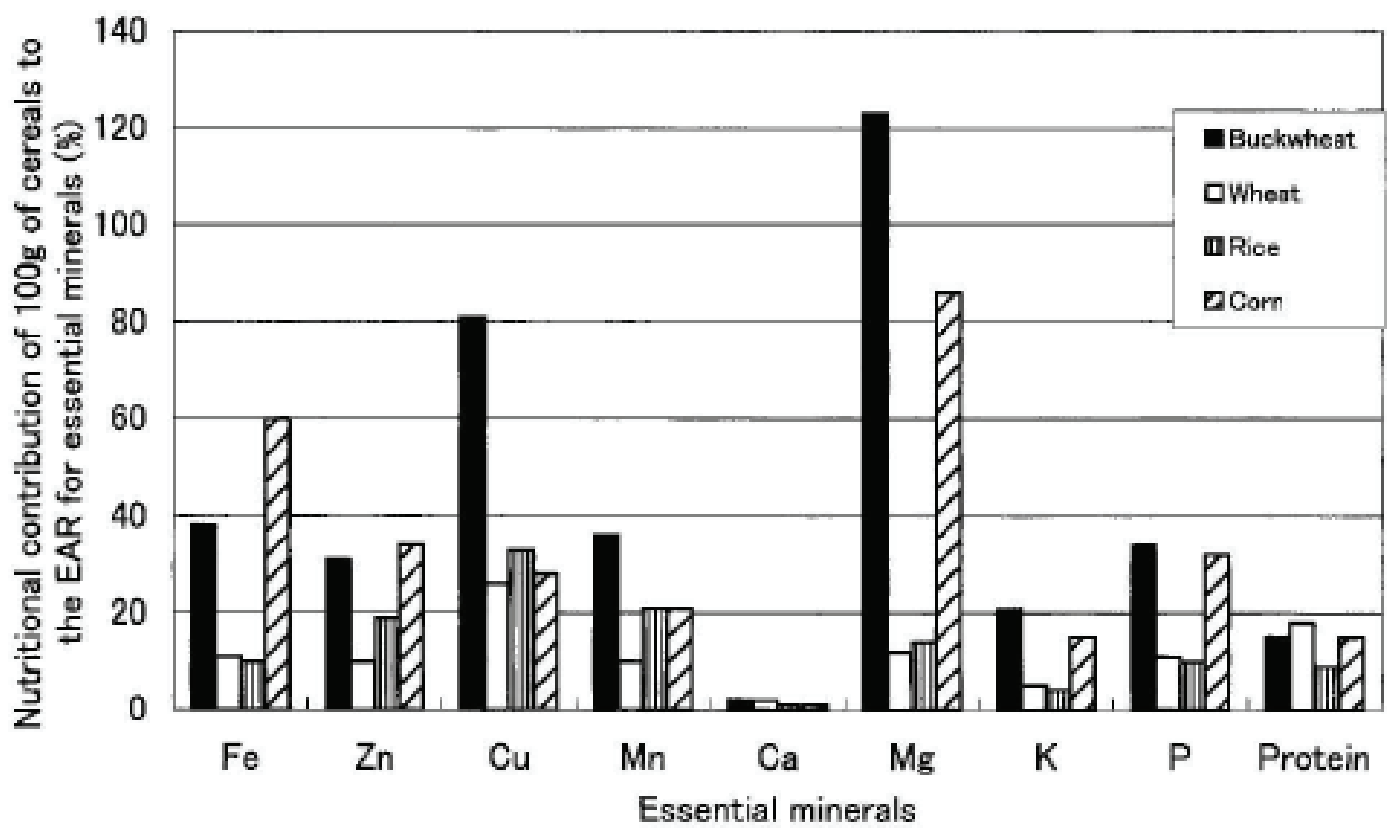

Figure 1.4. Nutritional comparison in mineral characteristics between buckwheat and cereals. Source: Ikeda et al., 2006.

Buckwheat leaves are rich in the antioxidant rutin that is extracted and used as an antidiabetic, antihaemorrhahic, and hypotensive drug, as well as a treatment against 
circulatory disorders and as a vasculoprotector (Quettier-Deleu et al., 2000; Zepp et al., 1966). Buckwheat's dark honey has the highest antioxidant activity of honeys from different floral sources such as clover, acacia, soybean, fireweed, tupelo, and Hawaiian Christmas berry (Gheldof et al., 2002). The level of antioxidants that can prevent cancer, high cholesterol and heart disease is twenty times higher than that of the other honey tested (Boland, 2013).

Besides grain production, food, and nutritional source, buckwheat is highly beneficial for agricultural ecosystems as a cover crop. It is recommended to grow buckwheat as a cover crop mainly to suppress weeds and improve soil tilth (Sattel et al., 1998). It grows and decomposes fast, which makes two major nutrients, phosphorus and potassium, available for the following crops (nitrogen accumulation and availability is not high); it mellows soil by decreasing soil bulk density; it enhances soil environment suppressing saprogenic microflora; and it needs minimum cultivation practices during the growing season (Sattel et al., 1998; Bjorkman, 2009; Parahin, 2010). Buckwheat is one of the best crops to provide nectar for honeybees, it attracts native pollinators and several important economic pests (Sattel et al., 1998; Treadwell \& Huang, 2008).

Buckwheat extracts immobile phosphorus from the soil and makes it available for the next crop in rotation. Enrichment of the soil by phosphorus could help farmers apply less fertilizer. Decreased amounts of phosphorus fertilizer are beneficial from two main points of view: less extraction of the mined phosphorus and prevention of the eutrophication of water bodies.

The ability of buckwheat to enrich soil with phosphorus could be attributed to the symbiosis with arbuscular mycorrhizal fungi (AMF) (Myers \& Meinke, 1994). There is 
little information available on AMF interaction with buckwheat. Even though buckwheat is usually referred as a nonmycorrhizal host crop (Vestberg et al., 2005; Smith \& Read, 2008), two articles discuss about buckwheat's symbiosis with AMF, which needs further research (Likar et al., 2008; Virant \& Kajfez-Bogataj, 1988). Researchers Annan and Amberger (1989) studied that buckwheat root exudates play a role in the phosphorus uptake.

Buckwheat residues, which decompose quickly, enrich soil with potassium as well (Bjorkman, 2009). Buckwheat's dry matter biomass production is relatively low, 2,000-4,000 lb per acre per year (Clark, 2007). Low biomass results in low organic matter and the nitrogen addition to the soil (Sattell et al., 1998). Another disadvantage is that because of low biomass and rapid decomposition, it is not suitable as surface mulch on erodible soils (Treadwell \& Huang, 2008).

Rapid growth of buckwheat makes it an ideal cover crop for use in rotations between cash crops (Sattell et al., 1998). Rapid germination and growth result in excellent weed control: it shades the soil, outcompetes weeds, and provides allelopathic effects (Clark, 2007).

Buckwheat flowers attract beneficial insects. Among them European bees (Apis mellifera L.), hoverflies, predatory wasps (Hymenoptera: Sphecidae, Eumenidae, and Vespidae), syrphid flies, tachinid parasitic flies, and insidious flower bugs are common visitors. Buckwheat decreases aphid densities and aphid-transmitted viruses in the cash crops. Buckwheat's living mulch reduces the number of whiteflies (Sattell et al., 1998; Treadwell \& Huang, 2008). 
In addition to the above listed benefits, buckwheat root exudates suppress plant pathogenic microflora in soil and provide detoxification of aluminum in acidic soils (Parahin, 2010). The crop is highly resistant to aluminum stress. It accumulates Al in leaves without showing toxicity symptoms. However, seeds accumulate much less Al than leaves (Chen et al., 2010). And also, it accumulates a large amount of lead in leaves, stem, and roots, without significant damage. Buckwheat is recognized as $\mathrm{Pb}$ hyperaccumulator' and could be utilized as potential phytoremediator of $\mathrm{Pb}$-contaminated soils (Tamura et al., 2005).

Regarding cultivation and management practices for buckwheat as a cover crop and as a cash crop, seeding rates for buckwheat as a cover crop are recommended in the range from 40 to $50 \mathrm{lb} /$ acre (drilled) and $70 \mathrm{lb} /$ acre (broadcasted). Higher seeding rates are needed if it is planted as a cash crop (Treadwell \& Huang, 2008; Bjorkman, 2009). It is recommended to plant it in rows 6 inches apart, drilled to a depth of $1 / 2$ to $1 \mathrm{inch}$, or broadcasted and incorporated with a light disking (Sattell et al., 1998).

Buckwheat seeds germinate in warm soil within 3-5 days. Plants grow rapidly, producing heart-shaped leaves, 2-3 inches in length, and begin to flower in 3-5 weeks. Single and hollow stem has side branches. A field of buckwheat covers the ground densely, reminds a blanket of white or pink flowers and remains flowering stage for several weeks, giving nectar and attracting pollinators. Flowers are self-sterile and need insects or wind to be cross-fertilized. To pollinate one hectare of buckwheat field, an average of 40000 bees are needed or one hive every 2 acres. Grain setting and maturity happens in 10-12 weeks after planting and all the seeds do not ripen at the same time. Typical grain yields in the northeastern US under good weather conditions could range 
from 1000 to $1500 \mathrm{lb}$ per acre. Usually buckwheat reaches a height of 2-4 feet, however hot and dry weather reduces the height of the crop. Diseases and insects are not a problem for buckwheat. It is sensitive to broadleaf herbicides (residues of atrazine, trifluralin, and sulfonylurea). Buckwheat requires no pesticides and little fertilizers. Thus, as a cash crop it can be easily grown as organic production system (Myers \& Meinke, 1994; Buckwheat, n.d.; Treadwell \& Huang, 2008; Bjorkman, 2009; Sattel et al., 1998; Zepp et al., 1996).

Buckwheat is not drought tolerant and early frost can damage the crop. It can germinate and grow at $45^{\circ} \mathrm{F}$ but optimal temperature is $55^{\circ} \mathrm{F}$ or higher, up to $104^{\circ} \mathrm{F}$. Buckwheat has a fibrous and shallow root system in the surface up to 10 inches deep. Buckwheat can grow in low fertility soils. Optimum $\mathrm{pH}$ range is 5.0-6.5; chernozem and grey forest soils are referred to be the best soil types for it. Buckwheat prefers sandy well-drained and well-aerated soil to clayey soil (Sattel et al., 1998; Treadwell \& Huang, 2008; Dovzhenko, 2010).

Buckwheat is a non-native crop to Florida. The Atlas of Florida Vascular Plants shows that Fagopyrum esculentum is found in Miami-Dade, Broward, Manatee, Volusia, Alachua, and Franklin counties (Wunderlin \& Hansen, 2008), Figure 1.5. As the USDA NRCS Plants Profile presents, buckwheat is widely distributed over almost the whole US (Figure 1.6). Even though buckwheat is not commonly grown in Florida's subtropical zone, few have suggested that buckwheat can be grown as a cover crop (Treadwell \& Huang, 2008; Huang 2009). Pei-wen Huang from the University of Florida, (2009) conducted research in Citra, FL, on the optimal planting period for buckwheat as a weed suppressive cover crop (spring and fall of 2007 and repeated in 2008). The optimal 
planting period is from middle April to beginning of May in spring and middle October in fall. Low temperatures in early spring and late fall suppress buckwheat growth (Huang, 2009).

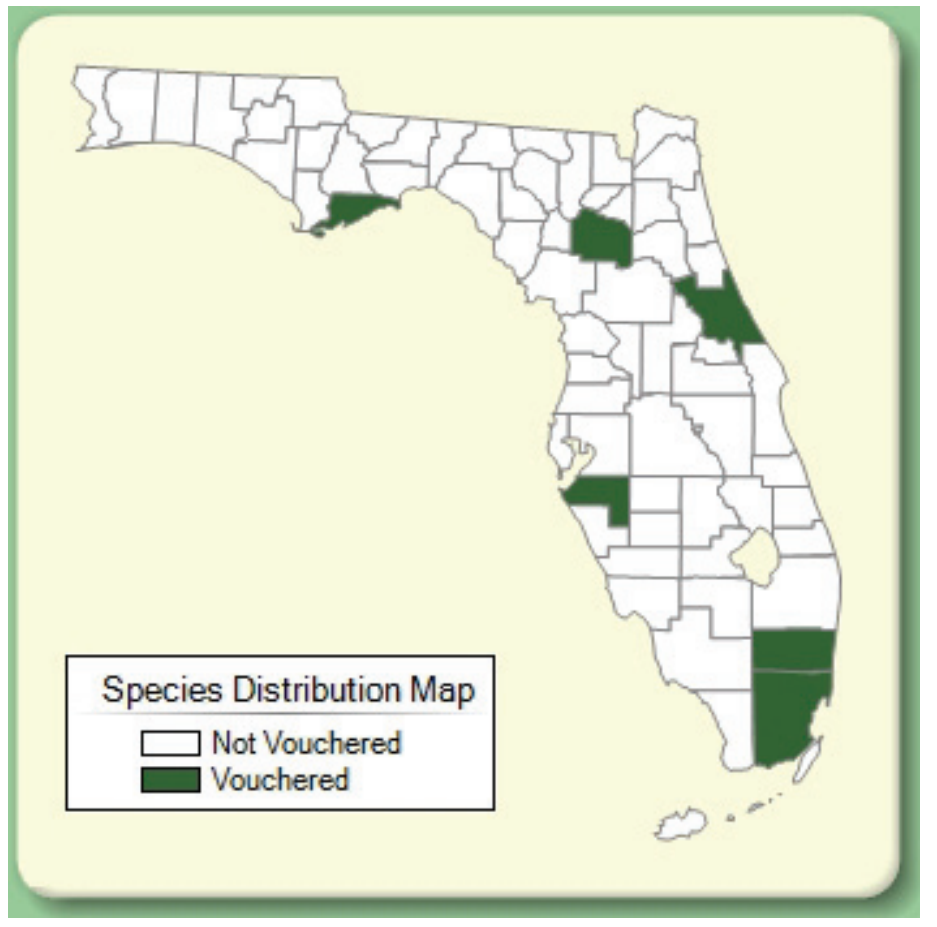

Figure 1.5. Distribution map of Fagopurum esculentum in Florida. Source: Wunderlin \& Hansen, 2008.

http://www.florida.plantatlas.usf.edu/Plant.aspx?id=1913 


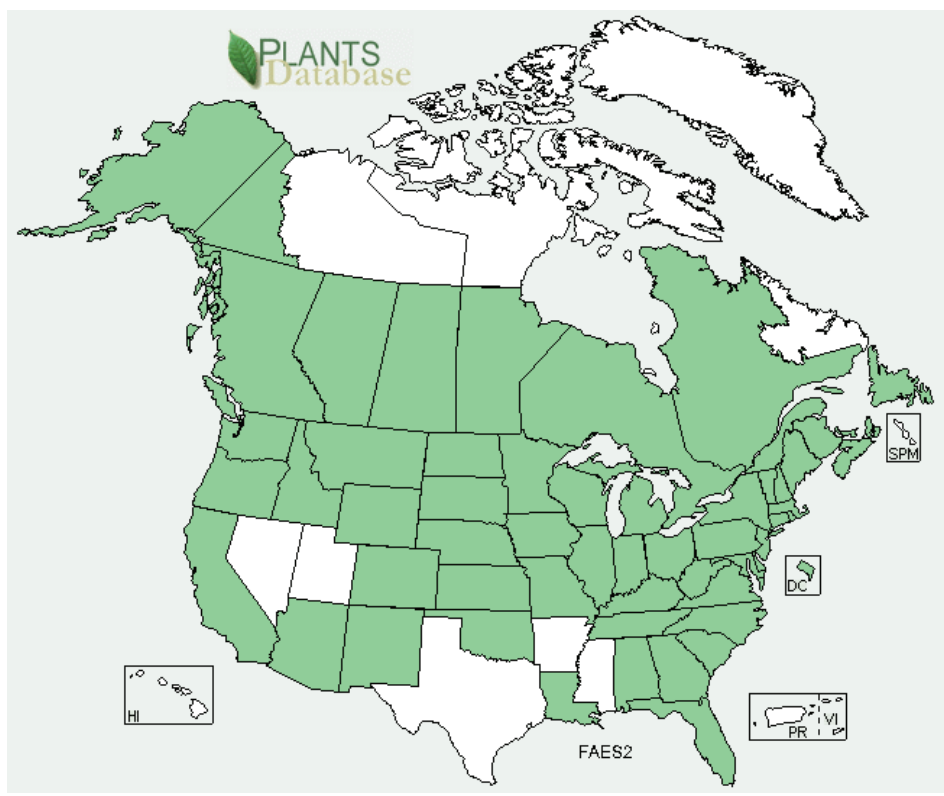

Figure 1.6. Distribution of Fagopurum esculentum Moench in the US. Source: USDA, NRCS, Plants Profile.

http://plants.usda.gov/java/profile?symbol=FAES2

Buckwheat grown for the purpose of this study during the winter months did show rapid germination and high growth rate. It enriched the soil with nutrients and decreased soil bulk density. It did not have any diseases and did not require pest control and fertilizers. It was colonized with arbuscular mycorrhizal fungi and showed different response to different soil types. The experimental details and results are in the following chapters. 


\section{CHAPTER 2}

\section{EXPERIMENT 1. GROWTH CHAMBER STUDY: MYCORRHIZAL COLONIZATION IN FAGOPYRUM ESCULENTUM}

\subsection{Introduction}

Mycorrhizal associations between fungi and plant roots are widespread in natural communities of terrestrial plants. There are six recognized types of mycorhrizal fungi (Heijden \& Sanders, 2002). Current study is focused on arbuscular mycorrhizal fungi (AMF) symbiosis with buckwheat. Both the host plant and the fungi benefit from the symbiotic relationships. The host plant supplies carbon to fungi and receives in return such benefits as increased uptake of macro- and micronutrients, resistance to soil-borne pests and soil-borne fungal diseases, drought resistance, tolerance to salinity and heavy metals, and improved soil aggregate stability (Gosling et al., 2006; Shetty et al., 1995).

Not all plant species form the symbiotic associations with AMF. The Brassicaceae and the Chenopodiaceae are non-mycorrhizal plants (Gosling et al., 2006). Those plants can be colonized by AMF but may not benefit from symbiosis. Buckwheat is usually referred as non-mycorrhizal host crop (Vestberg et al., 2005; Smith \& Read, 2008). However, two studies that show buckwheat's symbiosis with AMF (Likar et al., 2008; and Virant \& Kajfez-Bogataj, 1988). Likar et al. (2008) reported that Glomus species of AMF do colonize buckwheat roots and concluded that further study to determine the exact role of AMF in buckwheat growth and development is needed.

As mentioned earlier, buckwheat's main advantage as a cover crop is addition of phosphorus to soil. It has the ability to uptake significant amount of phosphorus ions and later, through decomposition of its residues, phosphorus is released back into soil. 
Enhanced phosphorus uptake is the primary benefit that AMF give to the host plant (Gosling et al., 2006). Generally, better plants growth is attributed to improved phosphorus nutrition because there are some species of plants that lack morphological or physiological mechanisms for efficient phosphorus uptake (Habte \& Osorio, 2001).

As reported in literature, buckwheat has ability to take up phosphorus and few micro-nutrients releasing root exudates, mild organic acids, which activate slow-releasing organic sources of phosphorus (Clark, 2007; Annan \& Amberger, 1989).

Understanding mycorrhizal status of buckwheat has important bearing on the subsequent cash crop. If buckwheat can support AMF symbiosis as a host then the cash crop that is dependent on mycorrhizal symbiosis will be benefited from the cover crop due enhanced AMF propagules in the soil (Vestberg et al., 2005). If, on the other hand, a non-mycorrhizal cover crop that is inhibitory to AMF is grown then the subsequent mycorrhizal cash crop will have reduced root colonization (Miller, 2000; Karasawa et al., 2002; Vierheilig et al., 2003).

For this experiment, the objectives were: 1) to analyze how buckwheat would benefit from the AMF symbiosis through growth rates; 2) to analyze the rates of phosphorus uptake by buckwheat colonized by AMF; 3) to analyze interactions between different phosphorus treatments (inorganic and organic) and AMF treatment; and 4) to examine the percent root colonization in buckwheat inoculated with AMF.

\subsection{Materials and Methods}

Plant material and treatment

The experiment was designed as 2 × 2 factorial with two independent variables: phosphorus ('Organic P' and 'Inorganic P') and mycorrhiza, AMF, inoculum ('AMF' 
and 'No AMF'). Thus, four treatments were sterile sand with organic phosphorus, sterile sand with inorganic phosphorus, sterile sand with AMF inoculum and organic phosphorus, and sterile sand with AMF inoculum and inorganic phosphorus (7 plants per pot and 3 pots for each treatment). The inoculum of AMF was added to 6 pots as a layer in sand before planting. AMF inoculant, utilized in this study, was a mixture of Glomus aggregatum, G. etunicatum, G. intraradices, G. mosseae, G. clarum, G. deserticola, G. monosporus, Gigaspora margarita, and Paraglomus brasiliantum. The standard fullstrength Hoagland solution was used to water plants in the pots with inorganic phosphorus treatment. The modified Hoagland's solution $\left(\mathrm{KH}_{2} \mathrm{PO}_{4}\right.$ was substituted by inositol hexaphosphoric acid, $\mathrm{C}_{6} \mathrm{H}_{16} \mathrm{~K}_{2} \mathrm{O}_{24} \mathrm{P}_{6}$ ) was used to water plants in the pots with organic phosphorus treatment. In this case organic phosphorus was regarded as less available phosphorus source for plants. It requires alteration in soil by AMF, soil microbes, or plant root exudates (Callaway et al., 1999).

The seeds of Fagopyrum esculentum were obtained from commercial source "Botanical Interests", Colorado that is certified organic. The experiment was carried out in a growth chamber with the light regime $12 \mathrm{~h}$ light/12 h night; day/night temperatures $22 / 18^{\circ} \mathrm{C}$ and moderate moisture conditions. The planting substrate was sand. To eliminate native microorganisms in substrate, the sand was sterilized by autoclaving at $121{ }^{\circ} \mathrm{C}$ for $30 \mathrm{~min}$. Seeds were treated with $0.5 \%$ sodium hypochlorite (bleach) for 10 min, washed with distilled water and planted into pots. Plants were maintained in a growth chamber during three and a half weeks. Then they were harvested and measured for growth rates, total phosphorus, and mycorrhizal analyses. Figure 2.1 shows buckwheat plants in the growth chamber (two weeks after the planting date). 


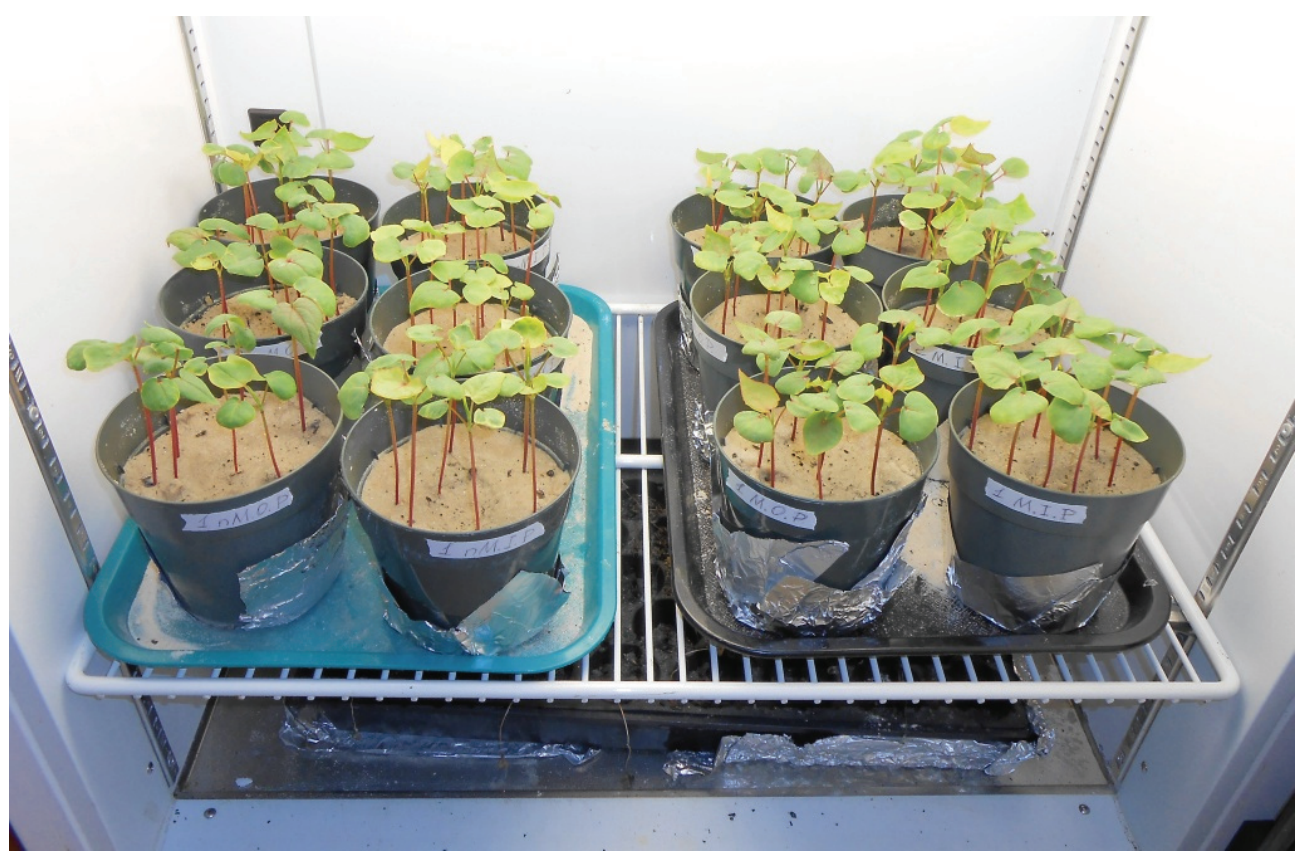

Figure 2.1. Buckwheat in the growth chamber (2 weeks old plants).

\section{Plant growth analysis}

Buckwheat plants growth rate was assessed by measuring height every week.

After harvesting the separated plant parts were oven-dried at $70{ }^{\circ} \mathrm{C}$. The weight of dry aboveground biomass (leaves and stems) and roots was measured and additional parameters as leaf mass ratio (LMR) and root:shoot ratio (RSR) were determined.

LMR $=$ Leaf dry mass / Total plant dry mass (Poorter et al., 2012).

RSR $=$ Roots dry mass / Leaves and stems dry mass (Rogers et al., 1996).

\section{Nutrients analysis}

Total phosphorus in the biomass was analyzed by acid digestion method followed by a colorimetric analysis of phosphate concentration of the extract (UV spectrophotometer 'Spectronic $20 \mathrm{D}+$ '). In addition to phosphorus, plants tissues were analyzed for total nitrogen and carbon by dry combustion, $950{ }^{\circ} \mathrm{C}$ ('TruSpec $\mathrm{CN}$ ' LECO). 


\section{Mycorrhizal assessment}

The method for staining the roots utilized potassium hydroxide, alkaline hydrogen peroxide and perchloric acid as bleaching agents and trypan blue as a dye. The stained roots in Petri dishes were examined under the microscope 'Olympus BX51' at 10-60 x magnification; small root pieces prepared as slides were examined with the microscope at $100 \mathrm{x}$ magnification.

The percentage of mycorrhizal colonization was determined in 50 intersections by the gridline intersect method.

\section{Statistical Analysis}

Data were tested by two-way ANOVA. The factors were Mycorrhiza, Phosphorus, and the Mycorrhiza x Phosphorus interaction $(\alpha=0.05)$. This analysis was done using PSAT v.14 software (SPSS Corp., Chicago, IL.).

\subsection{Results}

The results of the buckwheat plants growth analysis are presented in the Table 2.1. Results were significant for the aboveground biomass weight but not significant for the other factors at the 0.05 level. The results indicated that AMF did not influence plant height, development of larger leaf surface, or changes in root physiological functions but increased weight of the aboveground biomass.

Table 2.1. Treatment effect on buckwheat plants height, aboveground biomass weight, leaf mass ratio, LMR, and root:shoot ratio, RSR (means per pot).

\begin{tabular}{llllll}
\hline Factor & & Height, cm & Weight, g & LMR & RSR \\
\hline No AMF & Inorganic P & 12.10 & 0.72 & 0.68 & 0.32 \\
& Organic P & 12.21 & 0.94 & 0.69 & 0.39 \\
\multirow{2}{*}{ AMF } & Inorganic P & 13.60 & 1.2 & 0.68 & 0.33 \\
& Organic P & 12.14 & 1.09 & 0.67 & 0.39 \\
\hline
\end{tabular}




\begin{tabular}{lllll}
\hline Analysis of variance: & & & & \\
Mycorrhiza & $0.188 \mathrm{~ns}$ & $0.001 *$ & $0.693 \mathrm{~ns}$ & $0.970 \mathrm{~ns}$ \\
Phosphorus & $0.219 \mathrm{~ns}$ & $0.449 \mathrm{~ns}$ & $0.991 \mathrm{~ns}$ & $0.152 \mathrm{~ns}$ \\
Mycorrhiza x Phosphorus & $0.148 \mathrm{~ns}$ & $0.032 *$ & $0.383 \mathrm{~ns}$ & $0.852 \mathrm{~ns}$ \\
\hline
\end{tabular}

$* P<0.05$.

ns $=$ not significant.

The results of total phosphorus, nitrogen, and carbon content analyses are given in the Tables 2.2-2.3. Table 2.2 presents $\mathrm{P}, \mathrm{N}$, and $\mathrm{C}$ concentrations in the buckwheat biomass and Table 2.3 presents $\mathrm{P}, \mathrm{N}$, and $\mathrm{C}$ uptake that is concentration multiplied per weight of a plant.

Table 2.2. Treatment effect on phosphorus (P), nitrogen (N), and carbon (C) concentrations in buckwheat leaves and stems.

\begin{tabular}{|c|c|c|c|c|}
\hline \multicolumn{2}{|l|}{ Factor } & \multirow{2}{*}{$\begin{array}{ll}\mathrm{P}, \% \\
0.52\end{array}$} & \multirow{2}{*}{$\begin{array}{l}\mathrm{N}, \% \\
4.10\end{array}$} & \multirow{2}{*}{$\begin{array}{l}\mathrm{C}, \% \\
39.63\end{array}$} \\
\hline No AMF & Inorganic $\mathrm{P}$ & & & \\
\hline & Organic $\mathrm{P}$ & 0.35 & 3.39 & 41.46 \\
\hline \multirow[t]{2}{*}{$\mathrm{AMF}$} & Inorganic $\mathrm{P}$ & 0.46 & 3.80 & 39.23 \\
\hline & Organic $\mathrm{P}$ & 0.29 & 3.18 & 41.56 \\
\hline \multicolumn{5}{|c|}{ Analysis of variance: } \\
\hline \multicolumn{2}{|c|}{ Mycorrhiza } & $0.029 *$ & $0.280 \mathrm{~ns}$ & $0.923 \mathrm{~ns}$ \\
\hline \multicolumn{2}{|c|}{ Phosphorus } & $0.000 * *$ & $0.017 *$ & $0.201 \mathrm{~ns}$ \\
\hline \multicolumn{2}{|c|}{ Mycorrhiza x Phosphorus } & $0.980 \mathrm{~ns}$ & $0.839 \mathrm{~ns}$ & $0.869 \mathrm{~ns}$ \\
\hline \multicolumn{5}{|c|}{$\begin{array}{l}* P<0.05 \\
* * P<0.01 \\
\mathrm{~ns}=\text { not significant. }\end{array}$} \\
\hline \multicolumn{5}{|c|}{$\begin{array}{l}\text { Table 2.3. Treatment effect on phosphorus }(\mathrm{P}) \text {, nitrogen }(\mathrm{N}) \text {, and carbon }(\mathrm{C}) \text { uptake in } \\
\text { buckwheat leaves and stems. }\end{array}$} \\
\hline \multicolumn{2}{|l|}{ Factor } & $\mathrm{P}, \mathrm{mg}$ & $\mathrm{N}, \mathrm{mg}$ & $\mathrm{C}, \mathrm{mg}$ \\
\hline \multirow[t]{2}{*}{ No AMF } & Inorganic $\mathrm{P}$ & 0.533 & 4.227 & 40.82 \\
\hline & Organic $\mathrm{P}$ & 0.471 & 4.571 & 55.96 \\
\hline \multirow[t]{2}{*}{$\mathrm{AMF}$} & Inorganic $\mathrm{P}$ & 0.797 & 6.529 & 67.47 \\
\hline & Organic $\mathrm{P}$ & 0.454 & 4.923 & 64.42 \\
\hline
\end{tabular}




\begin{tabular}{llll}
\hline Analysis of variance: & & & \\
Mycorrhiza & $0.001 * *$ & $0.004 * *$ & $0.000 * *$ \\
Phosphorus & $0.000^{* *}$ & $0.095 \mathrm{~ns}$ & $0.007 * *$ \\
Mycorrhiza x Phosphorus & $0.000 * *$ & $0.019 *$ & $0.001 * *$ \\
\hline$* P<0.05$. & & \\
$* * P<0.01$. & & \\
ns $=$ not significant. & &
\end{tabular}

Figures 2.2-2.3 show absence and presence of AMF hyphae in buckwheat roots ('No AMF' treatment and 'AMF' treatment). Mycorrhizal colonization for the 'AMF' treatment was below $10 \%$ and the mycorrhizal colonization for the 'No AMF' treatment was $0 \%$.

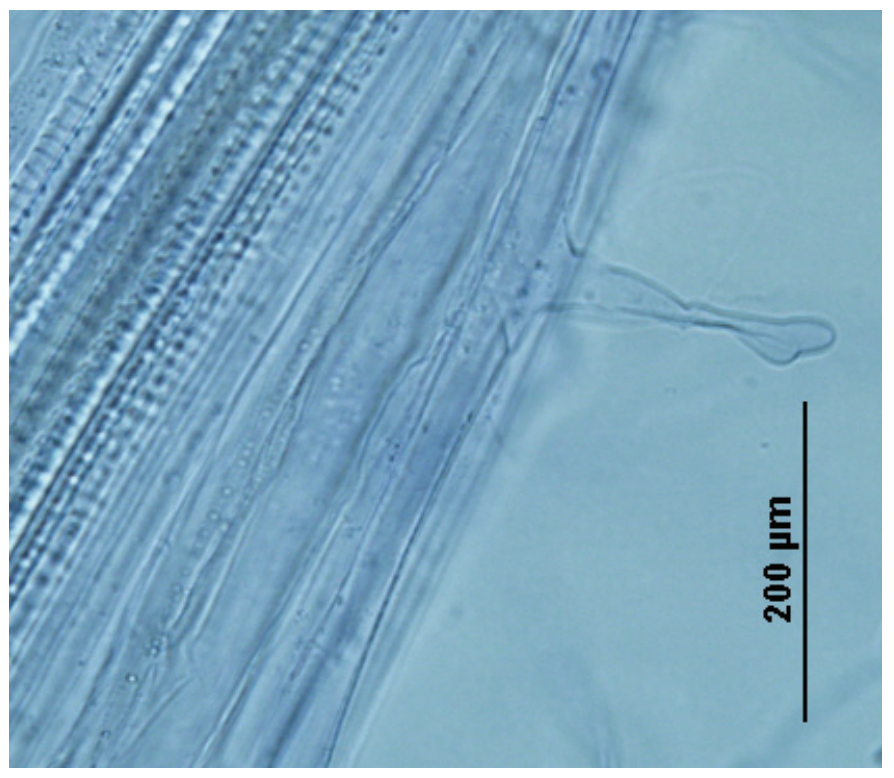

Figure 2.2. No AMF treatment (roots are clean). 


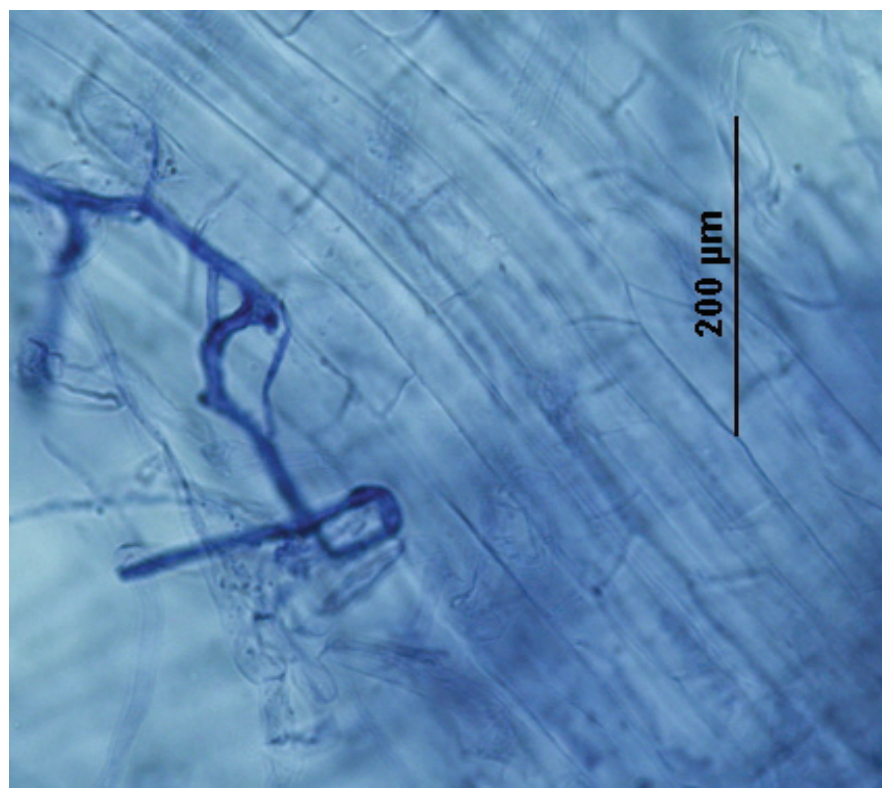

Figure 2.3. AMF treatment (AMF hyphae is distinguished).

Buckwheat plants grown in different soil types for the 'Experiment 3' (Chapter 4) was examined for the mycorrhizal colonization percent for the purposes of this chapter. Figure 2.4 presents AMF hyphae and arbuscules in buckwheat roots. Plants grown in calcitic soil from FIU Natural Preserve (Miami, FL), organic soil from two different plots in the FIU Organic garden (Miami, FL), and coastal plain soil from USDA ARS, Subtropical horticulture research station (Miami, FL) were all inoculated with AMF. Plants grown in organic soil from Tree Tops Park (Davie, FL) were not inoculated, roots were clean.

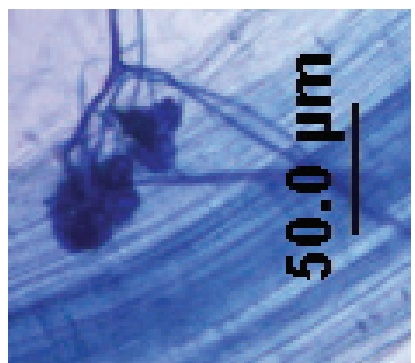

Calcitic soil,

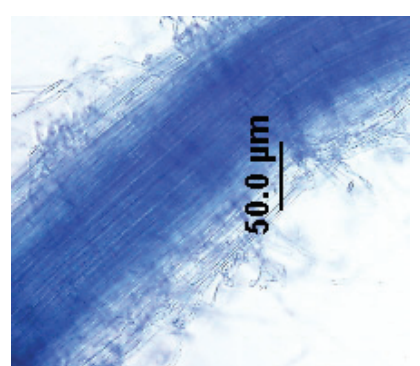

Organic soil, 
FIU Preserve

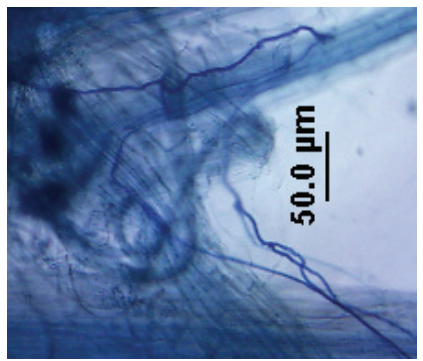

Organic soil,

Plot 1
Tree Tops Park

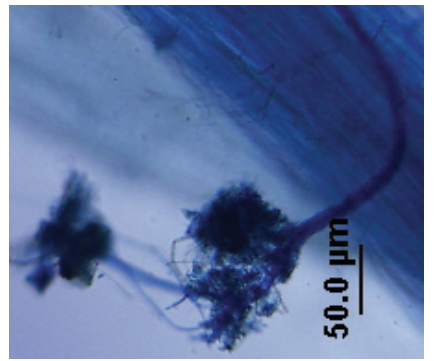

Organic soil,

Plot 2

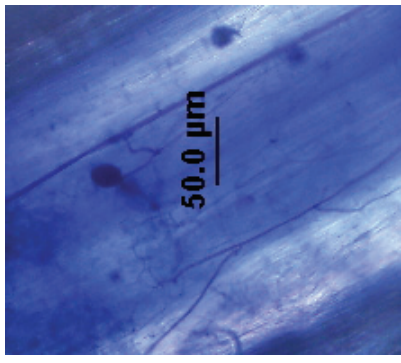

Coastal plain soil, USDA Station

Figure 2.4. Mycorrhiza arbuscules and hyphae in buckwheat roots. The image 'Tree Tops Park' shows no inoculation.

Results for percent root colonization are given in Table 2.4.

Table 2.4. Percent colonization of buckwheat plants with AMF grown in different substrates.

\begin{tabular}{c|c|c|c|c|c|c}
\hline & $\begin{array}{c}\text { Sterile } \\
\text { sand with } \\
\text { inoculum }\end{array}$ & $\begin{array}{c}\text { Calcitic } \\
\text { soil, FIU } \\
\text { Preserve }\end{array}$ & $\begin{array}{c}\text { Organic } \\
\text { soil, Tree } \\
\text { Tops } \\
\text { Park }\end{array}$ & $\begin{array}{c}\text { Organic } \\
\text { soil, } \\
\text { Plot 1 }\end{array}$ & $\begin{array}{c}\text { Organic } \\
\text { soil, } \\
\text { Plot 2 }\end{array}$ & $\begin{array}{c}\text { Coastal } \\
\text { plain soil, } \\
\text { USDA } \\
\text { Station }\end{array}$ \\
\hline $\begin{array}{c}\text { Colonization, } \\
\%\end{array}$ & 10 & 36 & 0 & 19 & 27 & 42 \\
\hline
\end{tabular}

\subsection{Discussion}

The two-way ANOVA indicated that there were no significant differences between the plants height, LMR, and RSR for mycorrhiza and phosphorus treatments. Interaction between phosphorus and mycorrhiza was not significant at the 0.05 level. However, there was significant difference for mycorrhiza treatment in plants weight and the interaction was significant (Table 2.1). The plants that were grown in the pots with AMF inoculum gained biomass more than plants without AMF inoculum. Pairwise comparisons did not give significant results, thus, the effect of AMF treatment was the same for organic or inorganic phosphorus. It can be concluded that AMF helped 
buckwheat plants gain biomass in both inorganic and organic phosphorus treatments. AMF treatment had no effect on leaf area per plant and root:shoot ratio.

Phosphorus concentrations in buckwheat leaves and stems were significantly different for inorganic and organic phosphorus treatment $(P<0.01$; Table 2.2). As Table 2.3 shows, AMF increased inorganic phosphorus uptake for buckwheat significantly $(P<0.01)$; interaction between mycorrhiza and phosphorus treatments was significant as well $(P<0.01)$.

Buckwheat roots were found to absorb inorganic phosphorus in higher concentrations then organic phosphorus. The organic form of phosphorus (inositol hexaphosphoric acid) is less available form for plants uptake. Concentration of organic phosphorus for 'No AMF' and 'AMF' treatment were 0.35 and $0.29 \%$ respectively, the difference was significant at the 0.05 level (Table 2.2). Organic phosphorus uptake for the plants under 'No AMF' treatment was higher than for the plants under 'AMF' treatment ( $0.471 \mathrm{mg}$ versus $0.454 \mathrm{mg}$ per an average plant). It could be concluded that mycorrhizal fungi do not affect organic phosphorus uptake and that buckwheat does have ability to absorb less available form of phosphorus without the help of mycorrhizal fungi. Thus, this mechanism might be attributed to the root exudates mainly (Annan \& Amberger, 1989).

Regarding nitrogen and carbon uptake, there was significant difference in nitrogen and carbon in buckwheat tissues depending on whether it was inoculated with AMF or not $(P<0.01$; Table 2.3). Mycorrhizal fungi were found to enhance buckwheat growth and, thus, to increase nitrogen and carbon uptake in buckwheat. 
In this experiment the plants grown in the pots with sterile sand and AMF inoculum were colonized up to $10 \%$ that was the low colonization class (Kessler et al., 2009). Buckwheat grown in different soil types showed higher colonization rates, up to $42 \%$ (Table 2.4), except organic soil from the Tree Tops Park that might have not had mycorrhizal spores in it. In soil with mycorrhizal fungi spores buckwheat can be colonized from low to medium rates. Thus, if buckwheat is grown in rotations before a mycorrhizal host crop, it does not suppress mycorrhizal fungi in soil and might not affect colonization rates and yield of a subsequent host crop.

\subsection{Conclusion}

Buckwheat forms symbiosis with AMF and benefits from the symbiosis in gaining more aboveground biomass. AMF do not affect the plant's height, larger leaf area development, and do not change buckwheat's root:shoot ratio. AMF have significant effect on higher inorganic phosphorus uptake but do not affect rates of the organic phosphorus uptake. In the presence of mycorrhizal fungi buckwheat root colonization ranged from low to medium. This fact allows using buckwheat in crop rotations with subsequent mycorrhizal host crops as buckwheat does not suppress mycorrhizal propagules in soil. 


\section{CHAPTER 3}

\section{EXPERIMENT 2. ORGANIC GARDEN: BUCKWHEAT AS A COVER CROP}

\subsection{Introduction}

Buckwheat is an excellent choice for managing weeds, enriching soil with phosphorus and potassium, and decrease soil bulk density. Even though buckwheat does not produce much of organic matter and not a nitrogen fixing crop, it grows very quickly that makes it very valuable for the crop rotations (Clark, 2007). The objective of the experiment was to analyze soil improvement after growing buckwheat and incorporation of its residues into soil in Florida.

\subsection{Materials and Methods}

Study site

The field experiment was conducted at the FIU Agroecology organic garden plot. The seeds of Fagopyrum esculentum were obtained from commercial source "Botanical Interests", Colorado that is certified organic. The dimension of the experimental plot was $2.2 \mathrm{~m}$ by $1.2 \mathrm{~m}$. The experimental plot was a raised bed with the soil composed of Florida peat, dolomite, pine bark, and chipped oak as additional mulch. The soil type could be defined as organic soil. Buckwheat seeds were planted in rows $15 \mathrm{~cm}$ apart on the November 7, 2012. The seeds germinated on November 10 and flowering began on December 3. The plants were watered when needed. No fertilizers and pesticides were used during the experiment. The Figures 3.1-3.4 show buckwheat during three, four and five weeks after the planting date. Buckwheat was terminated after six weeks of growth, 
plant were chopped and mixed with surface soil and the residues were left for four weeks to decompose (Figure 3.4).
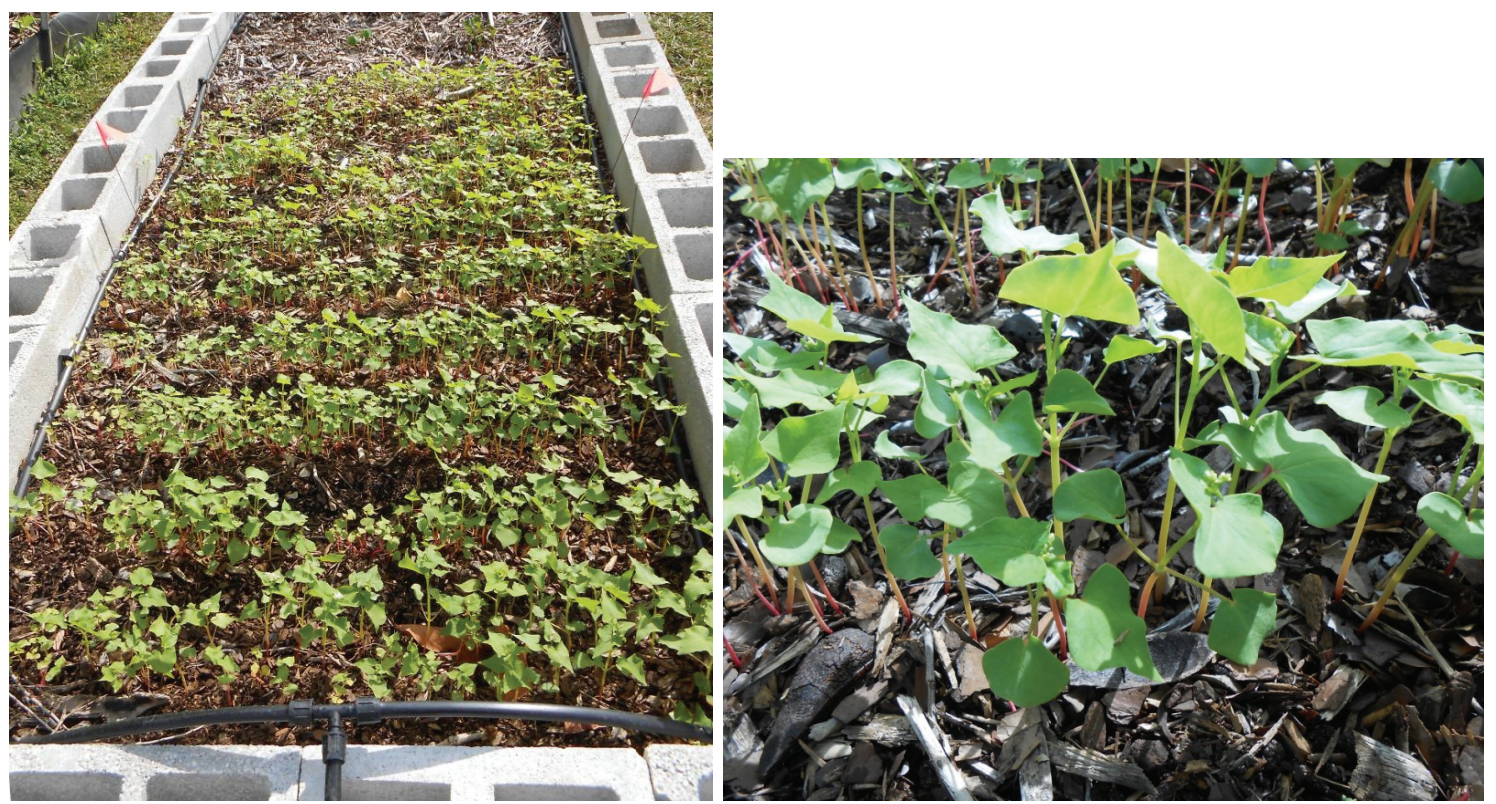

Figure 3.1. Buckwheat three weeks after the planting date.
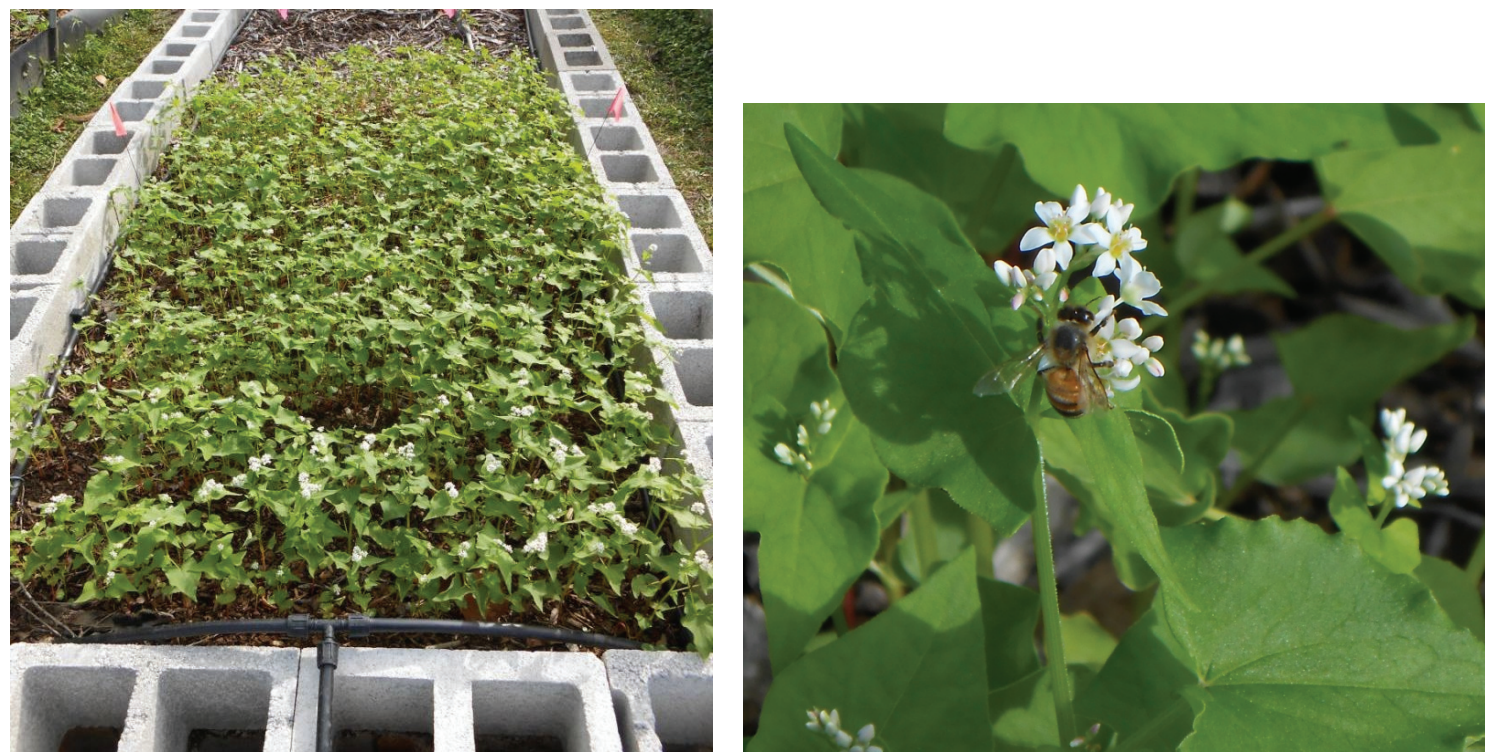

Figure 3.2. Buckwheat four weeks after the planting date. 


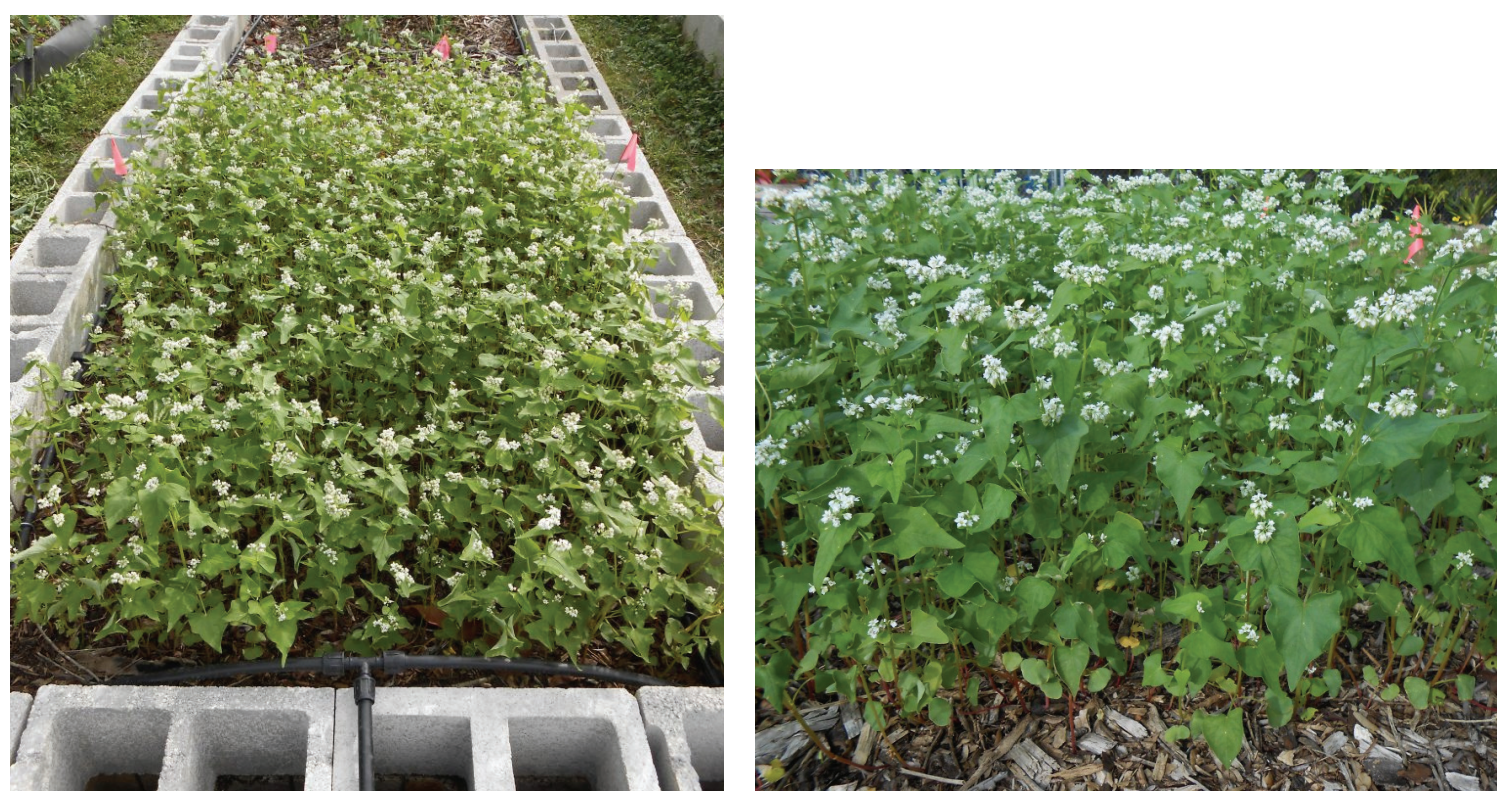

Figure 3.3. Buckwheat five weeks after the planting date.
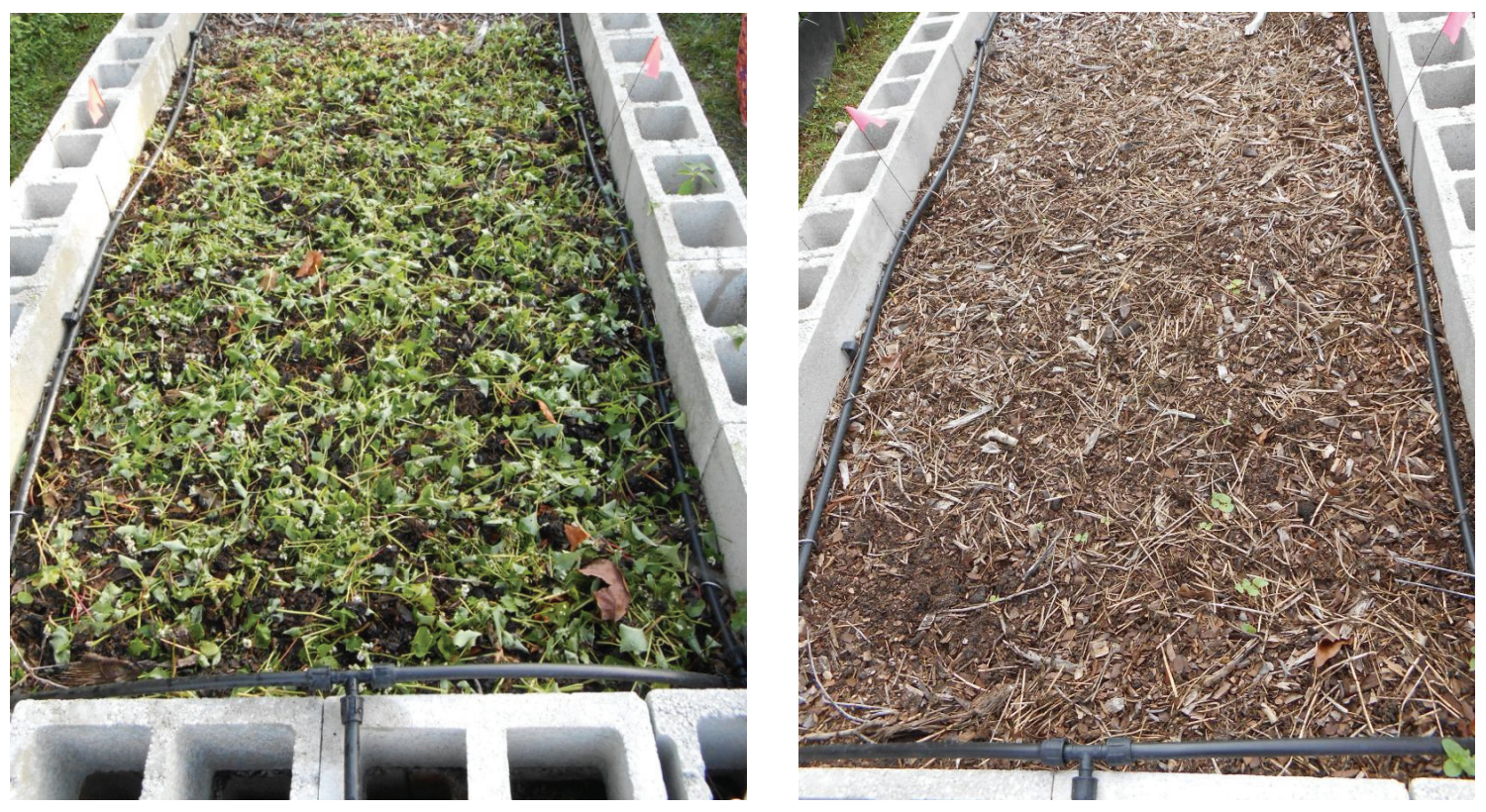

Figure 3.4. Buckwheat terminated (left) and four weeks after the termination (right). 


\section{Collection of Samples}

Initial soil samples were collected before planting and the final soil samples were taken four weeks after incorporating buckwheat residues into soil. Samples were taken from the top layer, $0-5 \mathrm{~cm}$ deep, and from the sub-surface layer, $5-15 \mathrm{~cm}$ deep; six replicates per layer. Soil samples were air dried and passed through a 2-mm sieve. Soil samples were grounded later to be prepared for nutrients and elemental analysis.

\section{Soil Analysis}

To measure soil $\mathrm{pH}$, soil and distilled water solution was prepared $(10 \mathrm{ml}$ of airdry soil and $20 \mathrm{ml}$ of distilled water) and $\mathrm{pH}$ was measured using "Orion 3 Star" $\mathrm{pH}$ meter. Soil texture was assessed by hydrometer method. Bulk density was calculated by dividing the mass of oven-dry soil by the volume of soil. Organic matter was measured by loss on ignition at high temperature (5-hour heating at $500^{\circ} \mathrm{C}$; Page, 1982).

Total soil nitrogen and total soil carbon were determined by using LECO "TruSpec CN" analyzer; samples for analysis consisted of 0.10-0.13 g soil weighed into a tared aluminum foil boat and loaded into the autoloader. Available phosphorus was measured using UV spectrophotometer "Spectronic $20 \mathrm{D}+$ ", using Olsen extraction (sodium bicarbonate) method. Extracts from $2 \mathrm{~g}$ of soil with sodium bicarbonate were shaken for $30 \mathrm{~min}$ and filtered. Total phosphorus, potassium, calcium, and magnesium were analyzed by iCAP 6000 ICP Emission Spectrometer. Extracts were prepared by double acid digestion method; $0.5 \mathrm{~g}$ of soil heated with $\mathrm{HNO}_{3}$ and $\mathrm{HCl}, 10 \mathrm{ml}$ each. 


\section{Statistical Analysis}

For each parameter of soil analysis, means were compared using pared samples ttest; significance was assessed at the 0.1 and 0.05 levels. The analysis was done using PSAT v.14 software (SPSS Corp., Chicago, IL.)

\subsection{Results}

Changes in soil characteristics in the top $(0-5 \mathrm{~cm})$ and in the sub-surface $(5-$ $15 \mathrm{~cm}$ ) layers are presented in Table 3.1 and Figures 3.5-3.9.

Table 3.1. Changes in soil $\mathrm{pH}$, bulk density, BD, soil organic matter, SOM, total nitrogen, $\mathrm{TN}$, total carbon, $\mathrm{TC}$, and carbon-nitrogen ratio $(\mathrm{C} / \mathrm{N})$ before planting buckwheat (B) and after incorporation and decomposition of buckwheat residues (A). $t$

\begin{tabular}{|c|c|c|c|c|c|c|}
\hline $\begin{array}{c}\text { Depth, } \\
\mathrm{cm}\end{array}$ & $\mathrm{pH}\left(\mathrm{H}_{2} \mathrm{O}\right)$ & $\mathrm{BD}, \mathrm{g} / \mathrm{cm}^{3}$ & SOM (\%) & TN (\%) & TC (\%) & $\mathrm{C} / \mathrm{N}$ \\
\hline & \begin{tabular}{l|l}
$\mathrm{B}$ & $\mathrm{A}$ \\
\end{tabular} & \begin{tabular}{l|l}
$\mathrm{B}$ & $\mathrm{A}$
\end{tabular} & \begin{tabular}{l|l}
$\mathrm{B}$ & $\mathrm{A}$
\end{tabular} & \begin{tabular}{l|l}
$\mathrm{B}$ & $\mathrm{A}$
\end{tabular} & $\begin{array}{ll}\mathrm{B} & \mathrm{I}\end{array}$ & \begin{tabular}{l|l}
$\mathrm{B}$ & $\mathrm{A}$
\end{tabular} \\
\hline $0-5$ & $8.02 \mid 7.89^{*}$ & $0.60 \mid 0.50$ & $32.40 \mid 42.46^{* *}$ & $0.77 \mid 1.51^{* *}$ & $17.83 \mid 26.92^{* *}$ & $23.16 \mid 17.83$ \\
\hline $5-15$ & \begin{tabular}{l|l|l|}
8.19 & 7.94
\end{tabular} & $0.90 \mid 0.63^{*}$ & $22.83 \mid 27.17$ & $0.70 \mid 1.40^{* *}$ & \begin{tabular}{l|l|l|}
14.12 & 19.68
\end{tabular} & $20.17 \mid 14.06$ \\
\hline
\end{tabular}

* Statistical significance at $P<0.10$ by paired samples $t$-test.

** Statistical significance at $P<0.05$.

$t$ Data are means of six replicates.

Buckwheat significantly decreased soil $\mathrm{pH}$ in the top layer $(P=0.086 ; \alpha=0.1)$. It significantly decreased soil bulk density in the sub-surface layer $(P=0.063 ; \alpha=0.1)$ but the top soil layer did not change significantly. Initial bulk density of the top layer was very low that is common for organic soil.

Soil organic matter increased significantly in the top layer $(P=0.029 ; \alpha=0.05)$. The residues were decomposing on the surface soil layer that allowed for accumulation of organic matter to the top soil layer. The same result was obtained for carbon because of the direct relationship between organic matter and high carbon concentrations in soil $(P=$ 
$0.013 ; \alpha=0.05$ ). The amount of nitrogen increased significantly in both layers (top layer: $P=0.000 ; \alpha=0.05 ;$ sub-surface layer $P=0.000 ; \alpha=0.05$ ).

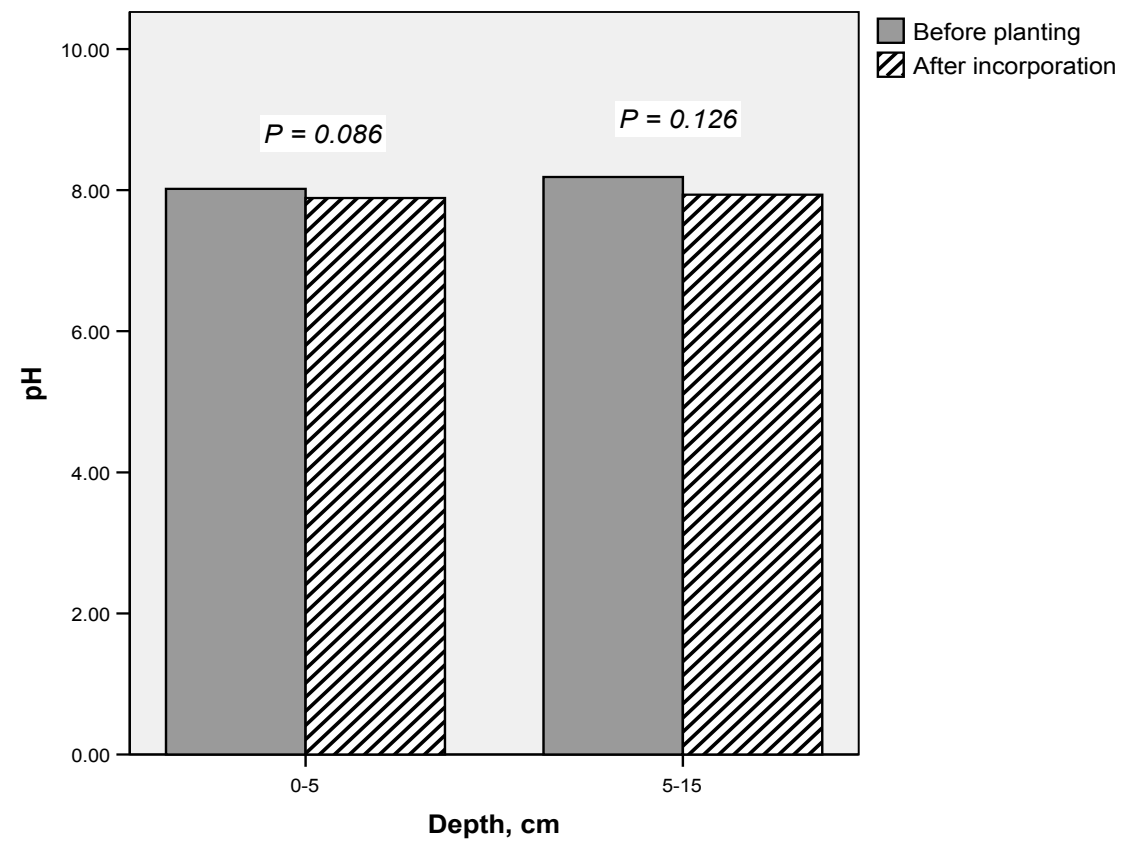

Figure 3.5. Changes in soil $\mathrm{pH}$ in relation to depth.

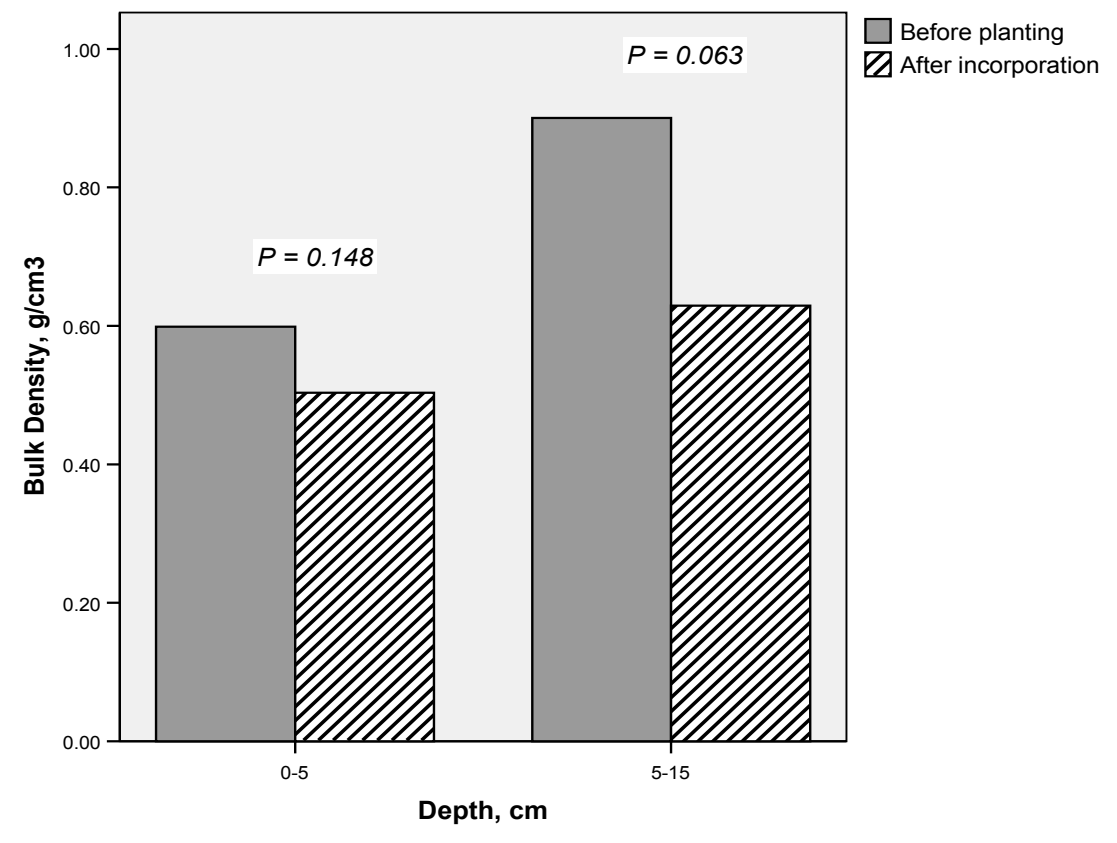

Figure 3.6. Changes in soil bulk density in relation to depth. 


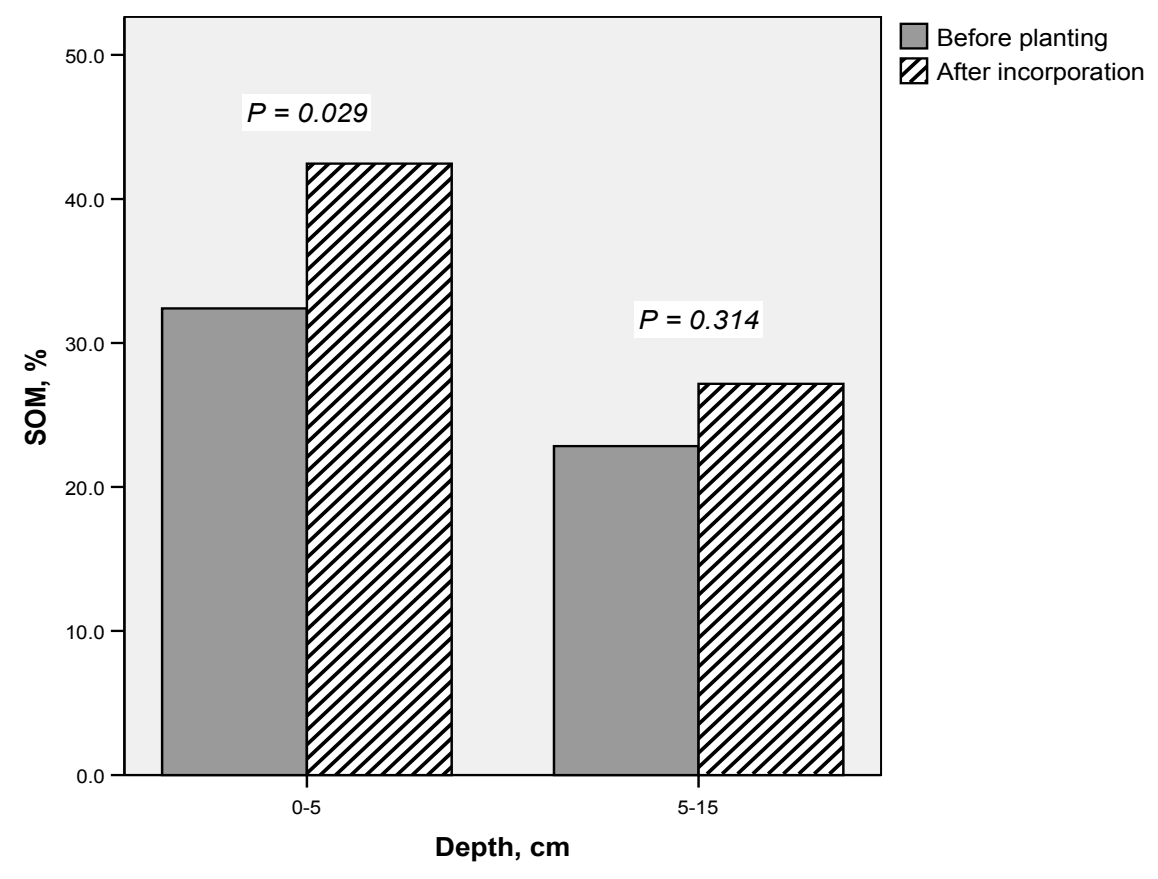

Figure 3.7. Changes in soil organic matter (SOM) in relation to depth.

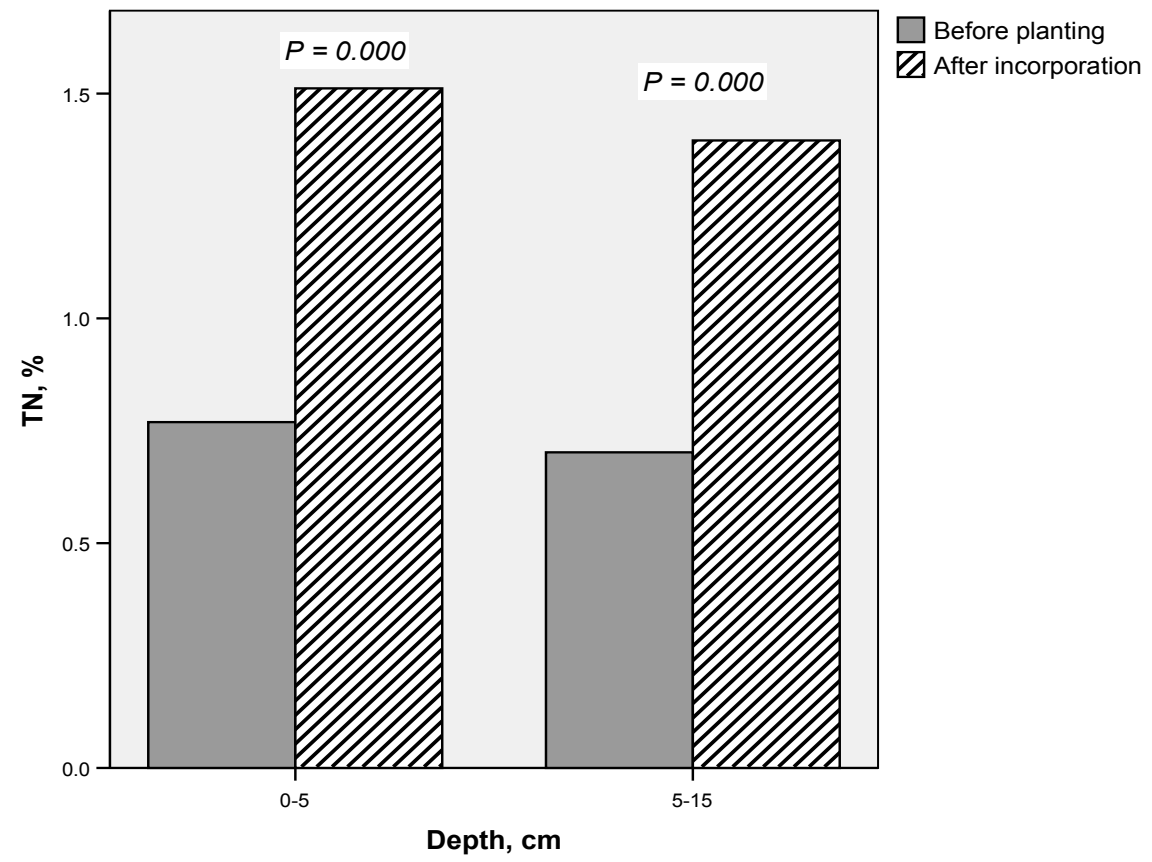

Figure 3.8. Changes in total nitrogen $(\mathrm{TN})$ in relation to depth. 


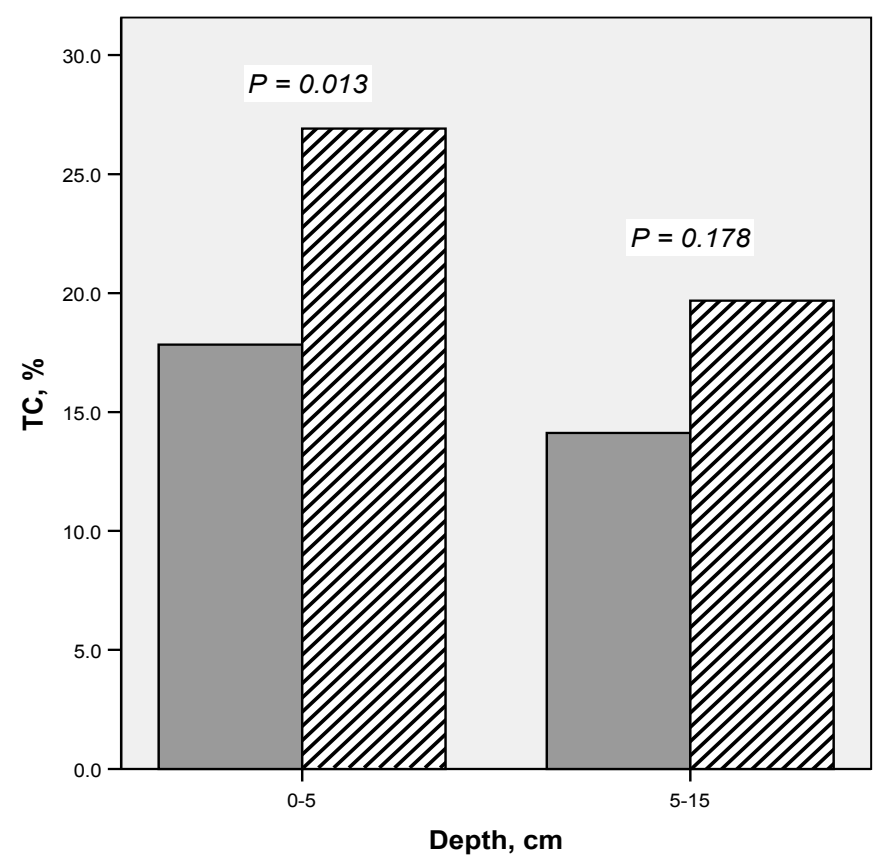

Figure 3.9. Changes in total carbon (TC) in relation to depth.

Results for available and total phosphorus, potassium, calcium, and magnesium concentrations in top and sub-surface soil layers are shown in Table 3.2 and Figures 3.103.14. As results indicates, only available phosphorus changed significantly in both layers (top layer: $P=0.010$; sub-surface layer: $P=0.013 ; \alpha=0.05$ ).

Table 3.2. Changes in available phosphorus, AP, total phosphorus, TP, potassium, K, calcium, $\mathrm{Ca}$, and magnesium, $\mathrm{Mg}$, before planting buckwheat (B) and after incorporation and decomposition of buckwheat residues (A). Mean differences are shown in parentheses. $t$

\begin{tabular}{|c|c|c|c|c|c|}
\hline $\begin{array}{l}\text { Depth, } \\
\text { cm }\end{array}$ & $\mathrm{AP}, \mathrm{ppm}$ & $\mathrm{TP}, \mathrm{ppm}$ & $\mathrm{K}, \mathrm{ppm}$ & $\mathrm{Ca}, \mathrm{ppm}$ & $\mathrm{Mg}, \mathrm{ppm}$ \\
\hline & \begin{tabular}{l|l}
$\mathrm{B}$ & $\mathrm{A}$
\end{tabular} & \begin{tabular}{l|l}
$\mathrm{B}$ & $\mathrm{A}$
\end{tabular} & \begin{tabular}{l|l}
$\mathrm{B}$ & $\mathrm{A}$
\end{tabular} & \begin{tabular}{l|l}
$\mathrm{B}$ & $\mathrm{A}$
\end{tabular} & $\bar{A}$ \\
\hline $0-5$ & $\begin{array}{c}82.4 \mid 135.3^{*} \\
(52.9)\end{array}$ & $\begin{array}{c}497.9 \mid 760.1 \\
(262.2)\end{array}$ & $\begin{array}{c}128.3 \mid 266.2 \\
(137.9)\end{array}$ & $\begin{array}{c}39986.7 \mid 42876.7 \\
(2890)\end{array}$ & $\begin{array}{c}3484.7 \mid 3708.7 \\
(224)\end{array}$ \\
\hline $5-15$ & $\begin{array}{c}112.7 \mid 150.9^{*} \\
(38.2)\end{array}$ & $\begin{array}{c}813.4 \mid 760.3 \\
(-53.1)\end{array}$ & \begin{tabular}{c|c}
95.8 & $\mid 72.3$ \\
$(-23.5)$
\end{tabular} & $\begin{array}{c}57676.7 \mid 55176.7 \\
(-2500)\end{array}$ & $\begin{array}{c}2870.0 \mid 2269.33 \\
(-600.67)\end{array}$ \\
\hline
\end{tabular}

* Statistical significance at $P<0.05$ by paired samples $t$-test.

$t$ Data are means of six replicates. 


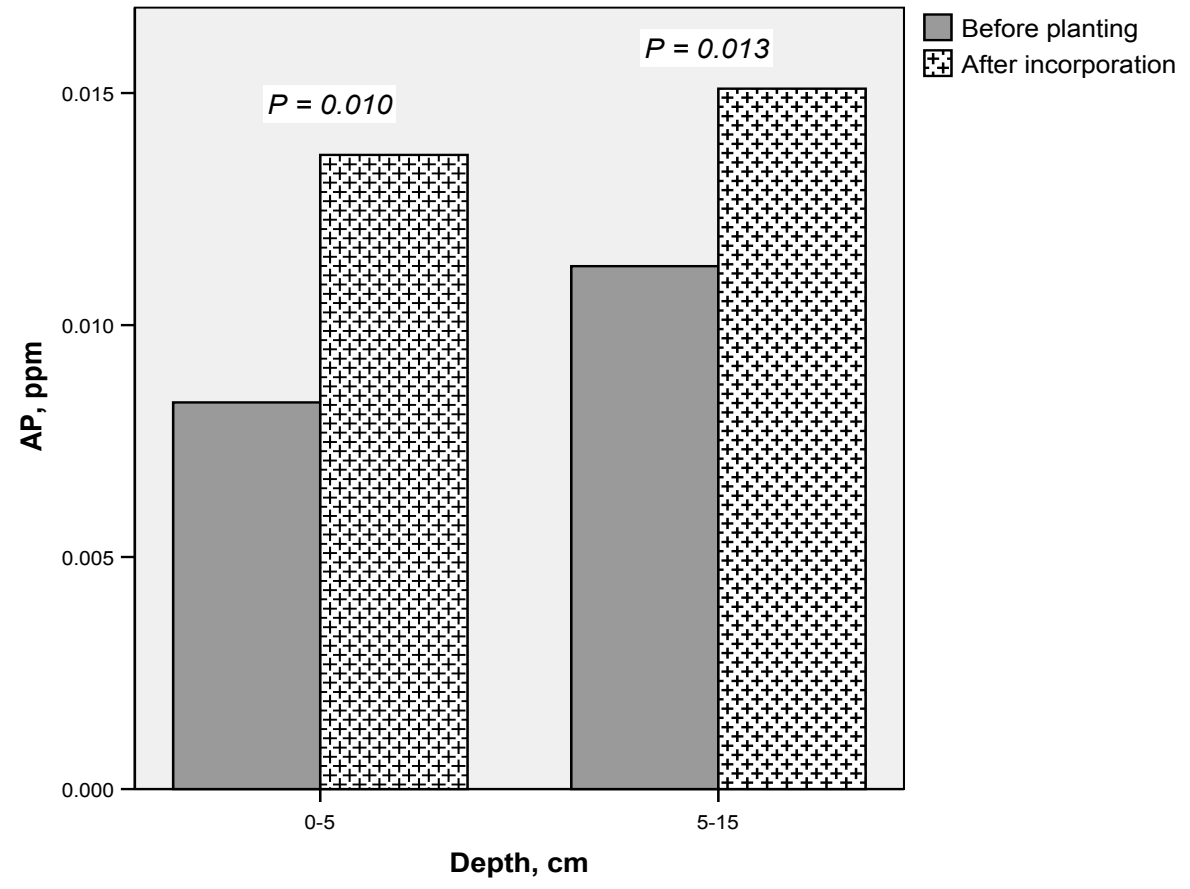

Figure 3.10. Changes in available phosphorus (AP) in relation to depth.

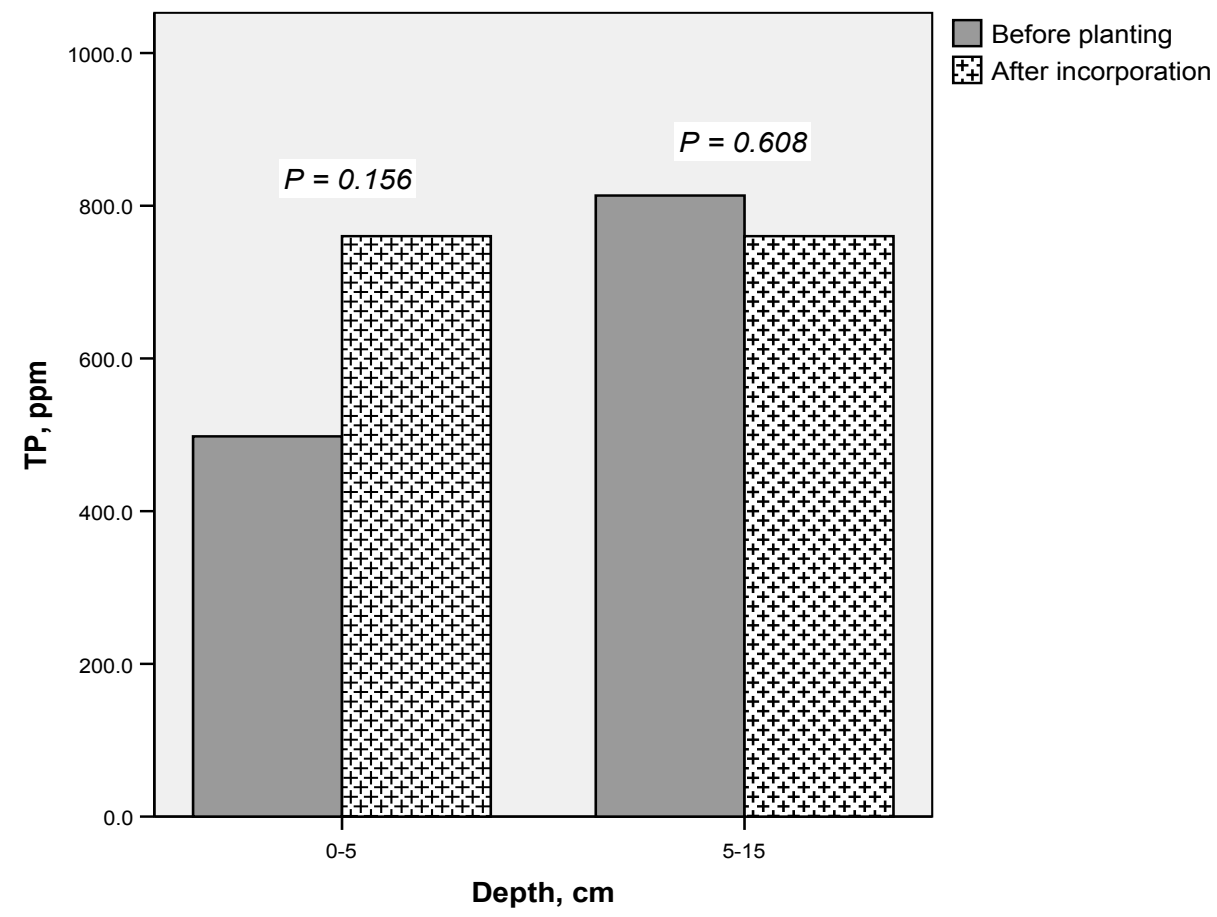


Figure 3.11. Changes in total phosphorus (TP) in relation to depth.

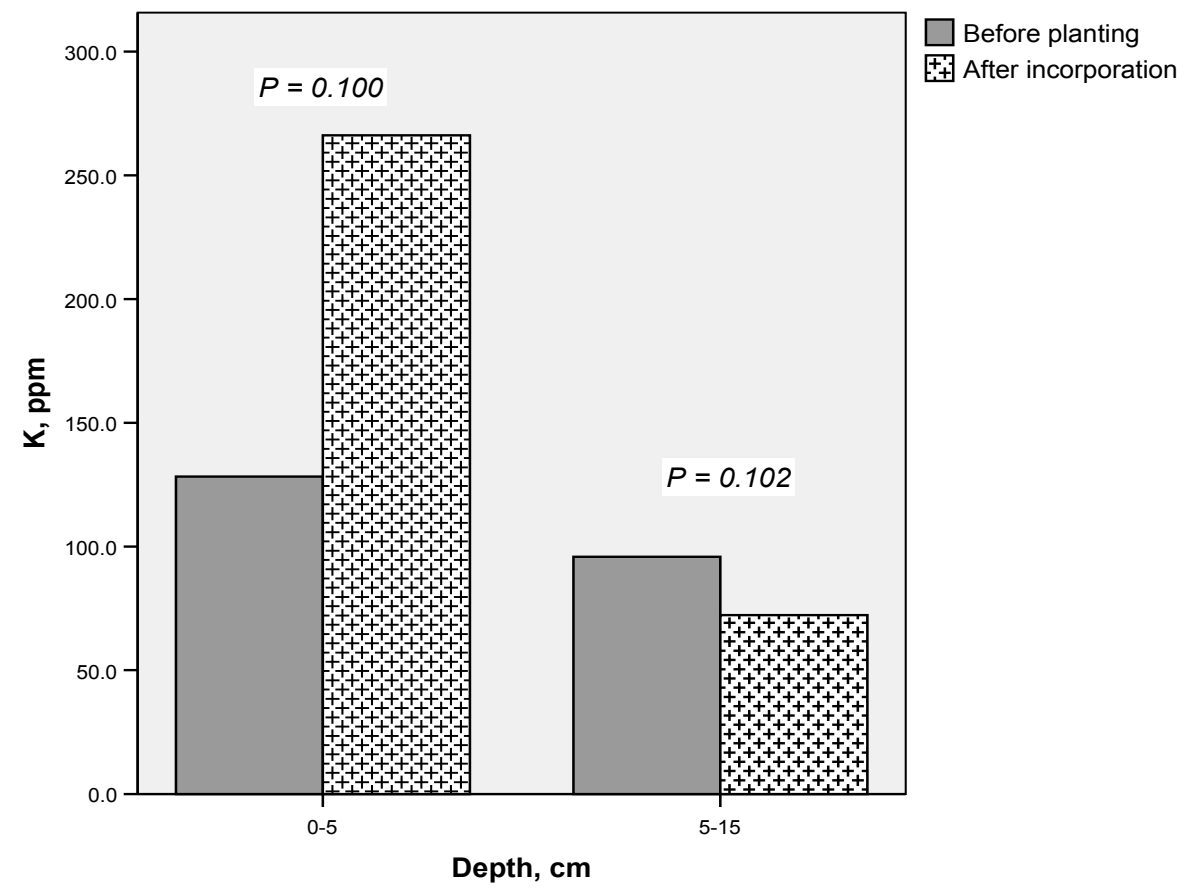

Figure 3.12. Changes in potassium $(K)$ in relation to depth.

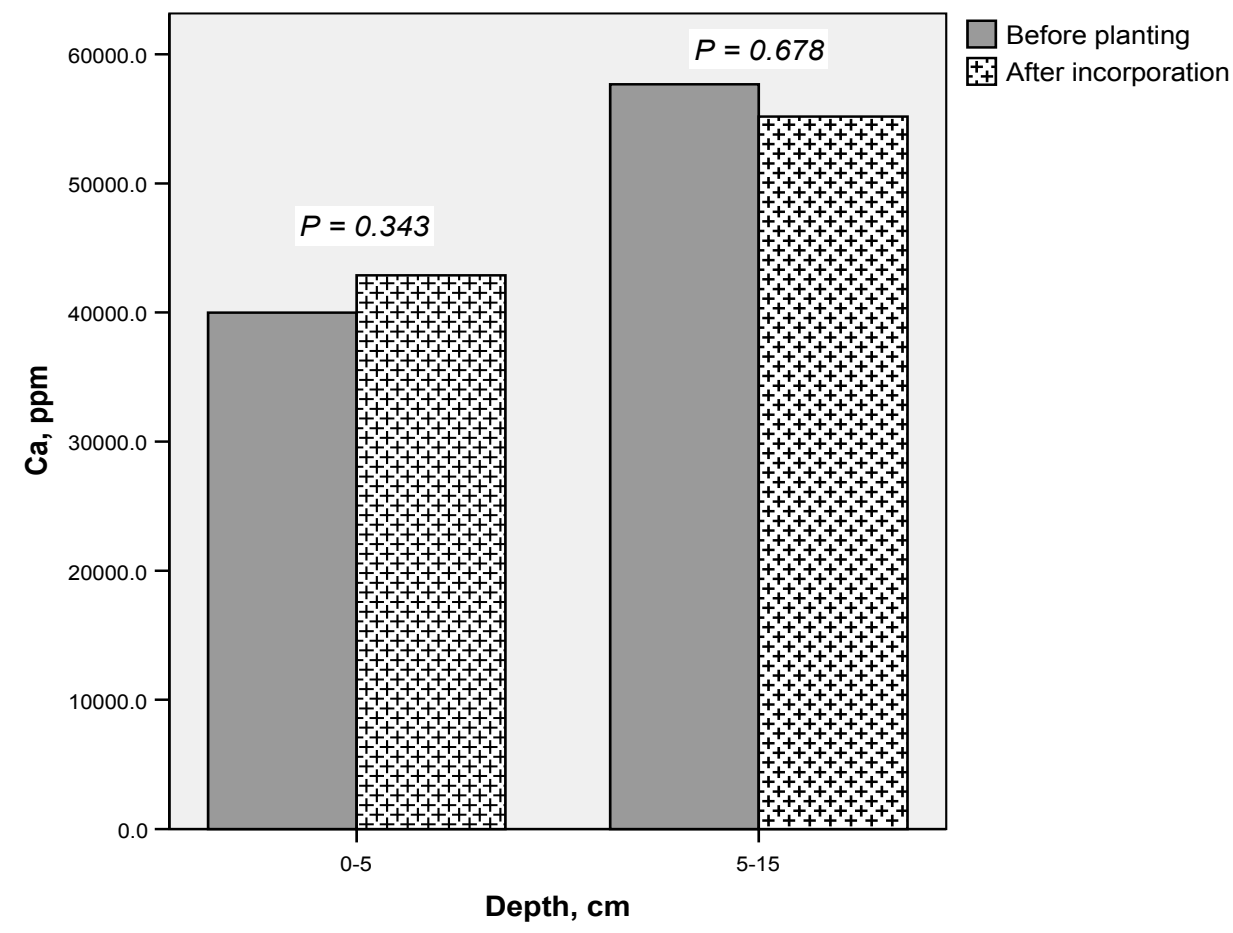


Figure 3.13. Changes in calcium $(\mathrm{Ca})$ in relation to depth.

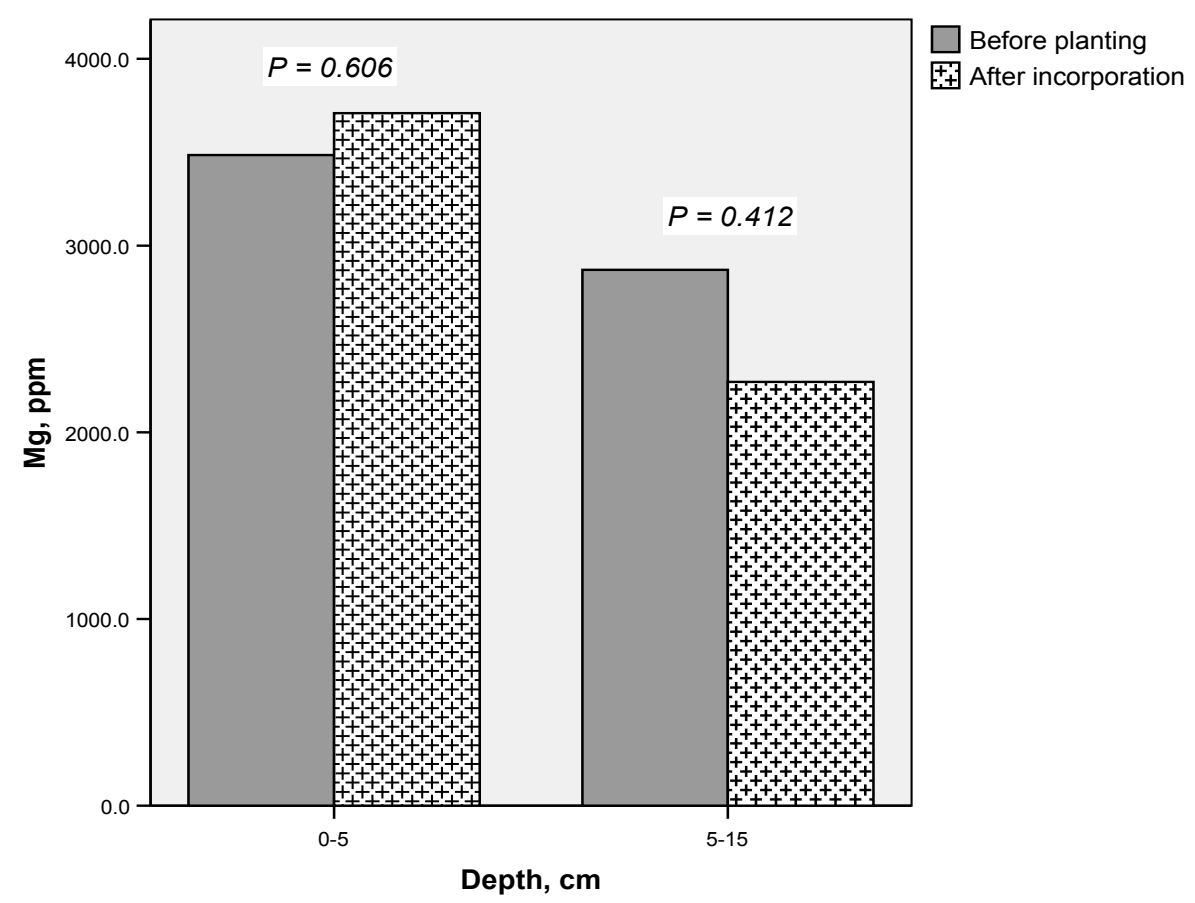

Figure 3.14. Changes in magnesium $(\mathrm{Mg})$ in relation to depth.

\subsection{Discussion}

Paired samples t-tests were conducted to evaluate the differences in soil characteristics before and after buckwheat was planted as a cover crop. The results indicated that in the top layer of the soil $\mathrm{pH}$ decreased, and organic matter content and total carbon increased significantly (Table 3.1). In the sub-surface soil layer $\mathrm{pH}$ did not change significantly because buckwheat residues were left for decomposition on the surface.

Significantly decreased soil bulk density in the sub-surface layer indicates buckwheat's root system ability to mellow soil. Such findings are supported by Thomas 
Bjorkman, Cornel University, and more research is recommended to be carried out (Bjorkman, 2009).

Concentrations of total nitrogen increased significantly in both layers of the soil (Table 3.1). The carbon-nitrogen ratio decreased after the residues were incorporated. This fact is explained by increased concentrations of total nitrogen in soil. Buckwheat is reported to be a very poor nitrogen scavenger and addition of nitrogen after buckwheat decomposition is regarded as very low (Sattel et al., 1998; Clark, 2007). However, significant increase in total nitrogen in the soil in this experiment supports a study that indicates enhanced biological nitrogen fixation near the buckwheat rhizosphere (Malceva et al., 1987). It is possible that stimulation of free living bacterial nitrogen fixing activity near buckwheat rhizosphere is caused by its root exudates, which are a good source of carbon for the bacterial population (Annan \& Amberger, 1989; Malceva et al., 1987).

One of the main focuses of this study was the change in the status of available phosphorus in soil before and after growing buckwheat as a cover crop. The results from this study are in agreement with the published reports that buckwheat is one of the best phosphorus scavengers among the cover crops. The increased concentrations of phosphorus, which is directly available for the next growth season, were significant for both top and sub-surface soil layers (Table 3.2). This fact allows farmers to reduce phosphorus fertilizer application on farms and, thus, decrease crop production costs and lower the possibility of the phosphorus runoff from the field. Calculations of the replaced fertilizer costs are given in the Chapter 6.

A distinctive pattern was observed for total phosphorus, potassium, calcium, and magnesium concentrations before and after utilizing buckwheat as a cover crop. The 
concentrations increased in the top layer but decreased in the sub-surface layer for all the elements. This could be explained as a movement and relocation of these elements from the sub-surface soil layers through a well-developed root system to the surface soil with the decomposed residues.

\subsection{Conclusion}

After growing buckwheat as a cover crop for six weeks and leaving residues to decompose for another four weeks, significant changes of soil characteristics were found. Soil bulk density decreased in the $5-15 \mathrm{~cm}$ layer; $\mathrm{pH}$ decreased in the top layer $(0-5 \mathrm{~cm})$; and available phosphorus concentration increased significantly in both layers. Despite the fact that buckwheat is not a nitrogen scavenger, concentration of nitrogen in soil significantly increased in both soil layers indicating stimulation of biological nitrogen fixation by bacteria in the rhizosphere. Buckwheat added potassium, magnesium, and calcium to the top soil relocating it from the deeper layers but the changes in concentrations were not significant.

As was expected, buckwheat did germinate, grow and decompose quickly. It did not have any diseases and did not need any type of pest control. It created dense canopy that shaded soil and suppressed weeds. Buckwheat was flowering after four weeks after planting and stayed so for two more, until termination, attracting pollinators.

Successful growth during late fall and winter in this study proves its suitability as a cover crop in South Florida. As a phosphorus scavenger it is a valuable plant that might be utilized by Florida's farmers in crop rotations. Chapter 4 shows relation of buckwheat's biomass production rates to different soil characteristic of some soil types found in Florida and Chapter 5 provides more details on planting dates for this region. 


\section{CHAPTER 4}

\section{EXPERIMENT 3. RESPONSE TO DIFFERENT SOIL TYPES}

\subsection{Introduction}

Buckwheat is a non-native plant found in Florida and almost no research work has been done regarding its agricultural use here. Buckwheat tolerates a wide range of soil types and can grow in soils with low fertility and low $\mathrm{pH}$. Therefore, the upper limit for $\mathrm{pH}$ is not mentioned in literature. Chernozem and grey forest soils are referred to be the best soil types for it (Dovzhenko, 2010). In general, sandy well-drained soils are more suitable for good buckwheat growth (Treadwell \& Huang, 2008).

The objective of this experiment was to analyze buckwheat response to different soil types in Florida.

\subsection{Materials and Methods}

The experiment was conducted in the FIU organic garden's shade house. The seeds of Fagopyrum esculentum were obtained from commercial source "Botanical Interests", Colorado that is certified organic. Seeds of buckwheat were planted in pots, eight per a pot (1 liter each) with different soil type. We used calcitic soil from FIU Natural Preserve (11200 SW $8^{\text {th }}$ St, Miami, FL), organic soil from two different plots in the FIU Organic garden (11200 SW $8^{\text {th }}$ St, Miami, FL), organic soil from Tree Tops Park (3900 SW 100 ${ }^{\text {th }}$ Ave, Davie, FL), and coastal plain soil from USDA ARS, Subtropical horticulture research station (13601 Old Cutler road, Miami, FL). The length of the experiment was till the plants' flowering that took four weeks (November 9, 2012 planted; December 7, 2012 - harvested). Oven dry aboveground biomass weight of the each plant was measured at the end of the experiment. 


\section{Soil Analysis}

Soil was analyzed for $\mathrm{pH}$, texture, bulk density, and organic matter. To measure $\mathrm{pH}$ soil and distilled water solution was prepared $(10 \mathrm{ml}$ of air-dry soil and $20 \mathrm{ml}$ of distilled water) and the $\mathrm{pH}$ recorded using "Orion 3 Star" $\mathrm{pH}$ meter. Soil texture was assessed by hydrometer method. Bulk density was calculated by dividing the mass of oven dry soil by the volume of soil. Organic matter was measured by loss on ignition at high temperature (5-hour heating at $500^{\circ} \mathrm{C}$; Page, 1982).

\section{Statistical Analysis}

For each soil characteristic, correlation analysis was performed. The analysis was done using PSAT v.14 software (SPSS Corp., Chicago, IL.)

\subsection{Results}

Germination rate for buckwheat for all soil types, except USDA station and Organic garden, Plot 2, was $100 \%$. In the pot, containing USDA station's soil, it was $50 \%$ and for organic garden soil from the Plot 2 it was $70 \%$. In four weeks after planting, buckwheat was harvested and oven-dried for 24 hours. Weight of the aboveground biomass (oven dry shoots and leaves) was measured and the results were summarized in Table 4.1. Soil was analyzed for $\mathrm{pH}$, bulk density, and organic matter (6 replicates for each soil type), and for texture (Table 4.2). Correlation coefficients were calculated among the buckwheat biomass weight and all measured soil parameters. The results of the correlation analyses are presented in Table 4.3 and Figures 4.1-4.4. 
Table 4.1. Aboveground dry biomass weight, $g$, for buckwheat plants grown in different soil types.

\begin{tabular}{llllll}
\hline & $\begin{array}{l}\text { Organic } \\
\text { garden, } \\
\text { Plot 1 }\end{array}$ & $\begin{array}{l}\text { Organic } \\
\text { garden, } \\
\text { Plot 2 }\end{array}$ & $\begin{array}{l}\text { FIU } \\
\text { Preserve }\end{array}$ & $\begin{array}{l}\text { Tree Tops } \\
\text { Park }\end{array}$ & $\begin{array}{l}\text { USDA } \\
\text { station }\end{array}$ \\
\hline Mean & 0.2283 & 0.1000 & 0.1617 & 0.2933 & 0.1233 \\
\hline SD & 0.1044 & 0.335 & 0.0917 & 0.0671 & 0.0305 \\
\hline
\end{tabular}

Table 4.2. Soil characteristics.

\begin{tabular}{llllll}
\hline & $\begin{array}{l}\text { Organic } \\
\text { garden, } \\
\text { Plot 1 }\end{array}$ & $\begin{array}{l}\text { Organic } \\
\text { garden, } \\
\text { Plot 2 }\end{array}$ & $\begin{array}{l}\text { FIU } \\
\text { Preserve }\end{array}$ & $\begin{array}{l}\text { Tree Tops } \\
\text { Park }\end{array}$ & $\begin{array}{l}\text { USDA } \\
\text { station }\end{array}$ \\
\hline $\mathbf{p H}$ & & & & & \\
Mean & 8.02 & 8.34 & 8.26 & 6.68 & 8.37 \\
SD & 0.19 & 0.07 & 0.04 & 0.21 & 0.08 \\
\hline BD, g/cm & & & & & \\
Mean & 0.75 & 0.75 & 1.33 & 0.67 & 0.83 \\
SD & 0.16 & 0.19 & 0.06 & 0.03 & 0.03 \\
\hline SOM, \% & & & & & \\
Mean & 32.6 & 34.1 & 5.04 & 29.4 & 28.7 \\
SD & 6.55 & 12.05 & 0.29 & 1.47 & 1.19 \\
\hline Texture & & & & & \\
Sand, \% & 83.5 & 84.0 & 97.5 & 93.75 & 75.0 \\
Silt, \% & 10.25 & 9.5 & 2.5 & 6.25 & 16.25 \\
Clay,\% & 6.25 & 6.5 & 0 & 0 & 8.75 \\
\hline
\end{tabular}

Table 4.3. Pearson correlation coefficients for the regression analysis of buckwheat biomass weight and soil characteristics.

\begin{tabular}{lllll}
\hline & SOM & BD & $\begin{array}{l}\text { Percentage of } \\
\text { sand }\end{array}$ & $\mathrm{pH}$ \\
\hline \multirow{2}{*}{ Biomass weight } & 0.028 & -0.189 & 0.348 & $-0.653^{*}$ \\
& Sig. 0.882 & Sig. 0.318 & Sig. 0.059 & Sig. 0.000 \\
\hline
\end{tabular}

* Correlation is significant at the 0.01 level (2-tailed). 


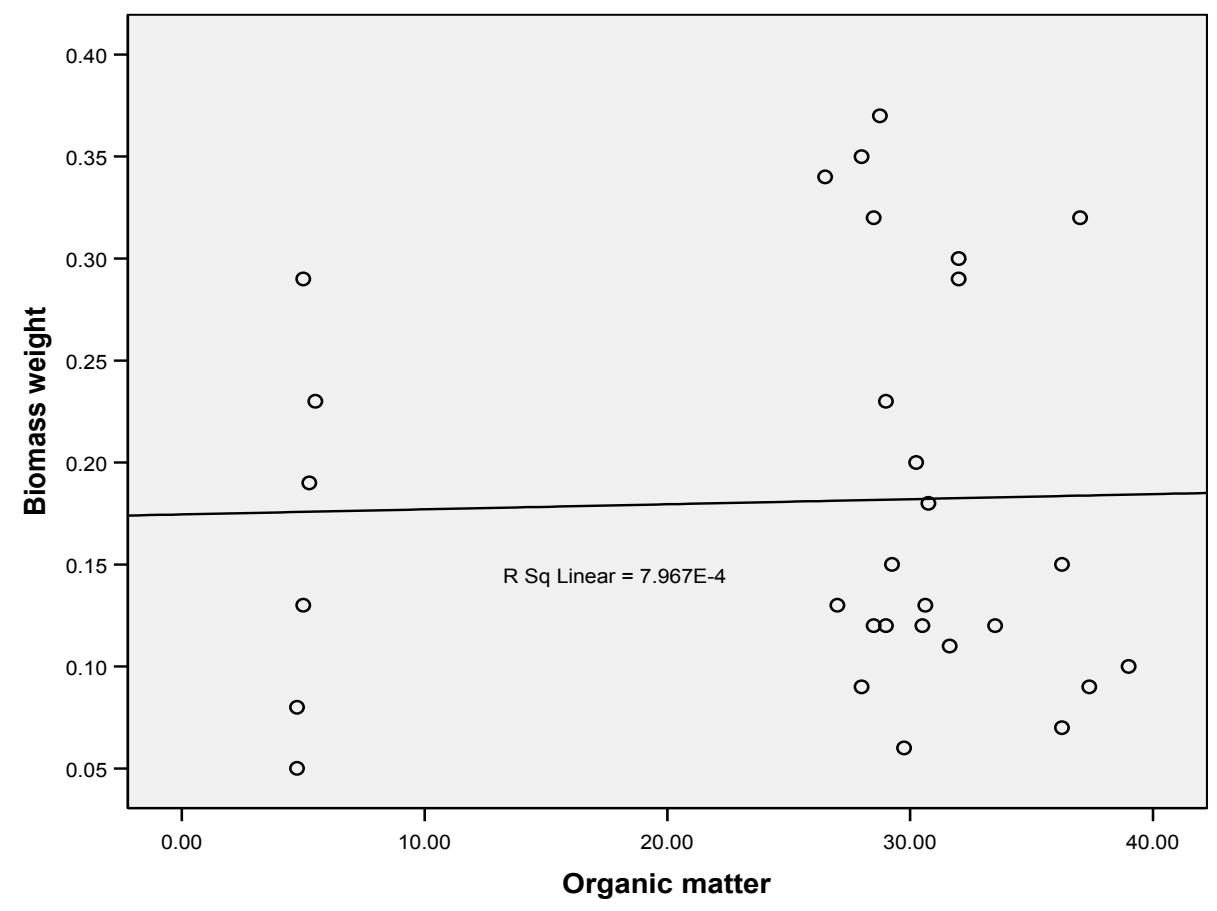

Figure 4.1. Relationship between soil organic matter (\%) and buckwheat biomass weight $(\mathrm{g})$.

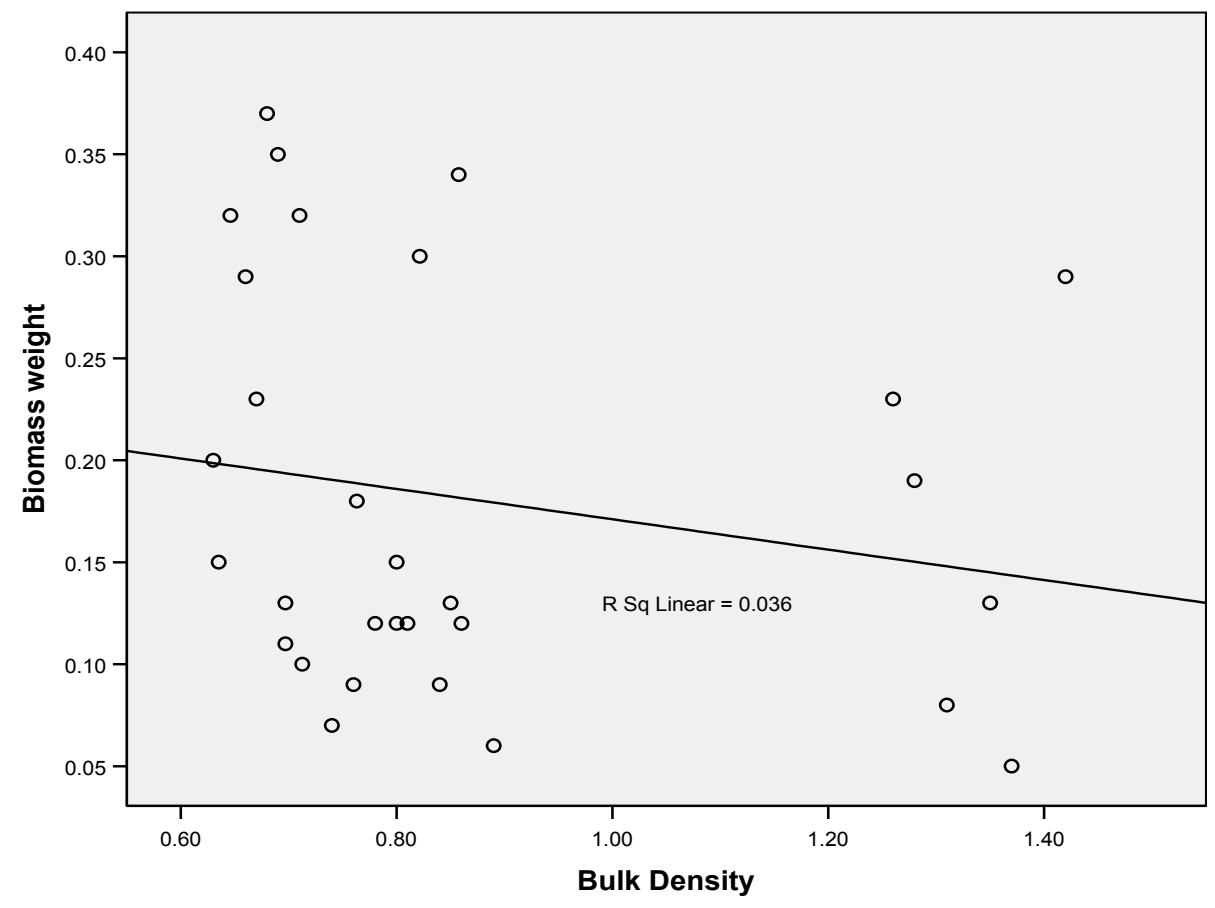

Figure 4.2. Relationship between soil bulk density $\left(\mathrm{g} / \mathrm{cm}^{3}\right)$ and buckwheat biomass weight $(\mathrm{g})$. 


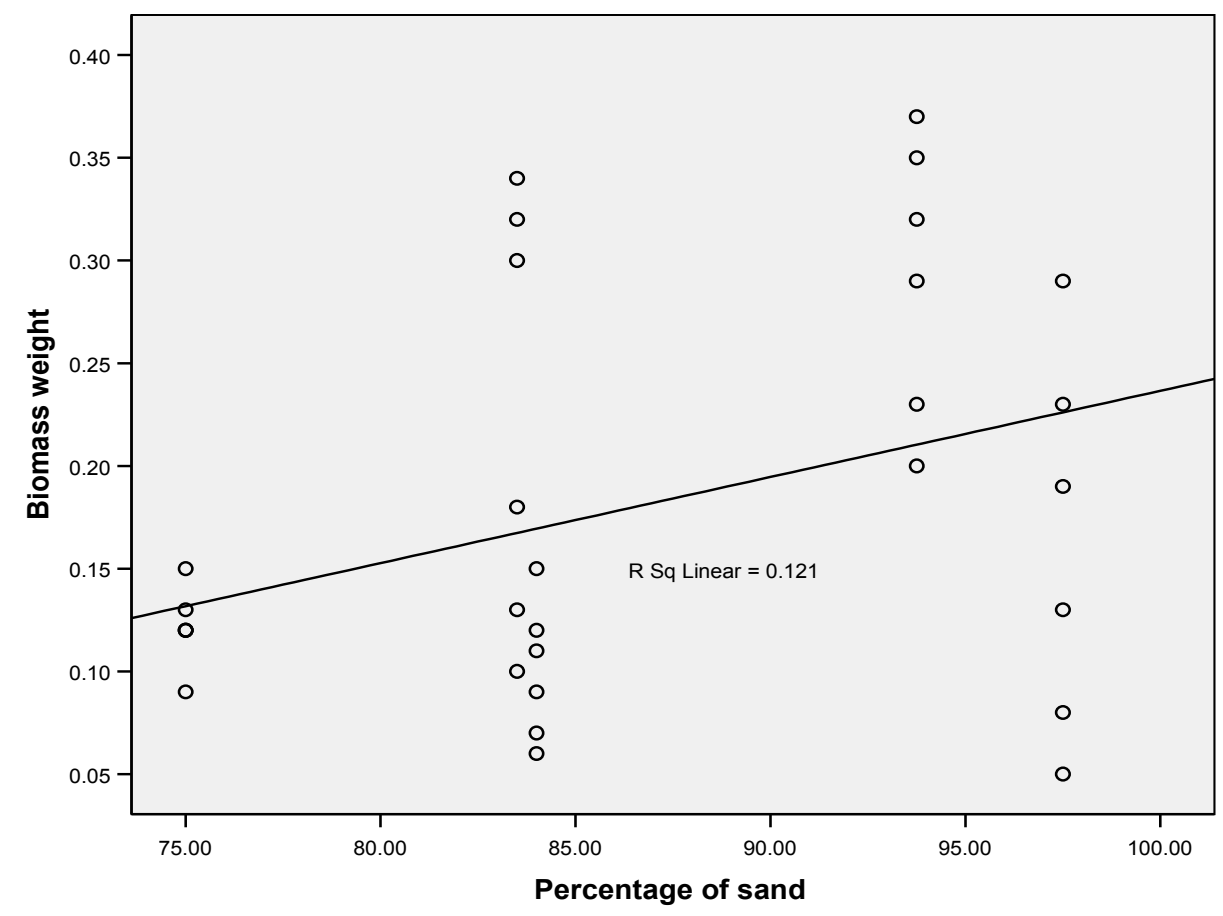

Figure 4.3. Relationship between texture ( $\%$ of sand) and buckwheat biomass weight $(\mathrm{g})$.

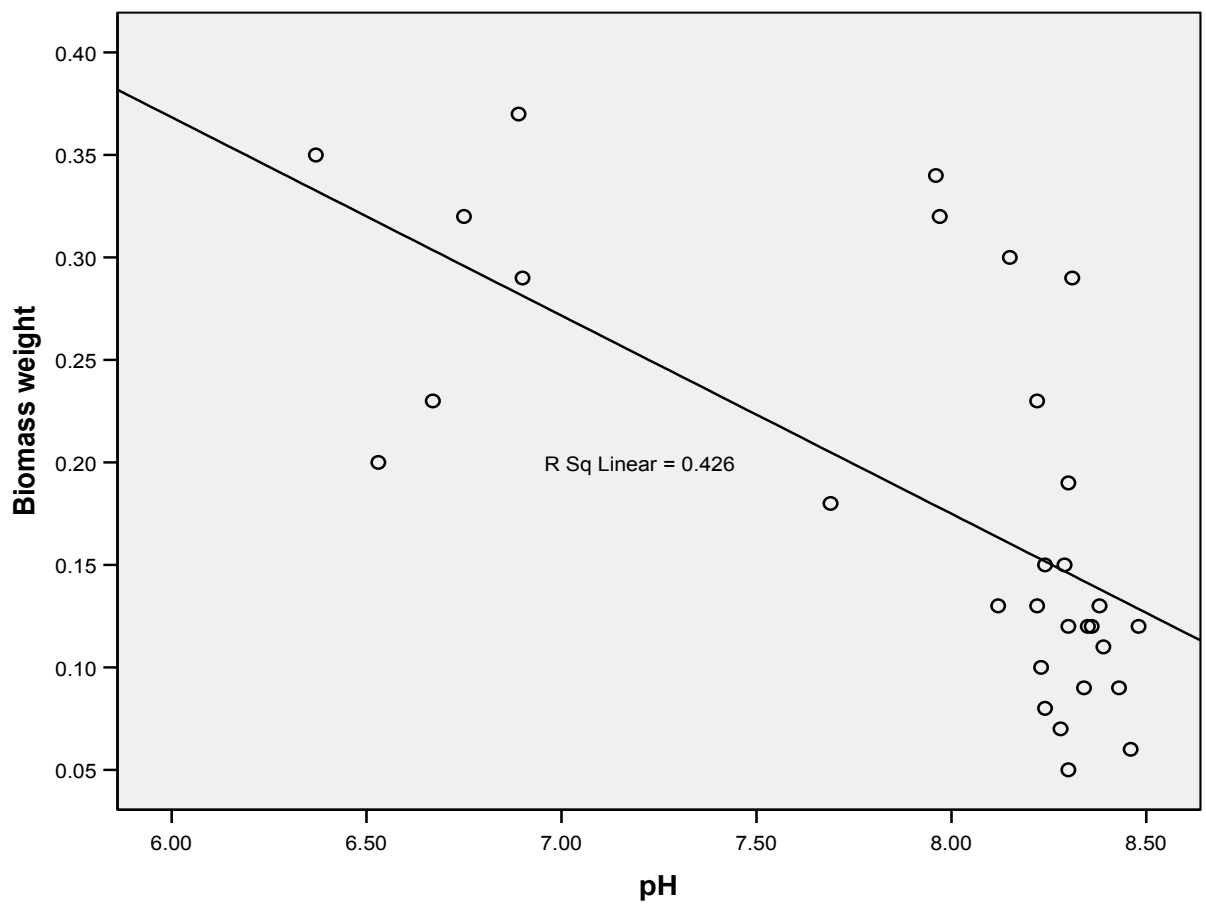

Figure 4.4. Relationship between $\mathrm{pH}$ and buckwheat biomass weight (g). 


\subsection{Discussion}

The objective of the experiment was to find which soil parameter would cause a significant impact on buckwheat growth. As previously mentioned, buckwheat tolerates low fertility soils, thus, soil was analyzed only for organic matter content (SOM, \%) as a general representative of the nutrients levels in a soil. As Table 4.3 and Figure 4.1 show, there was no correlation between SOM content and buckwheat growth (weight of aboveground biomass, g). Soil from FIU Preserve with SOM 5.04\% stimulated buckwheat growth better ( 0.1617 g per a dry plant) than soil from USDA station, which SOM was $28.7 \%(0.1233$ g per a dry plant).

Similar results were observed for bulk density $\left(\mathrm{BD}, \mathrm{g} / \mathrm{cm}^{3}\right)$ : FIU Preserve soil had the highest BD $1.33 \mathrm{~g} / \mathrm{cm}^{3}$ while the USDA station's soil with the lower BD $0.837 \mathrm{~g} / \mathrm{cm}^{3}$ gave lower plant biomass ( 0.1617 and $0.1233 \mathrm{~g}$ respectively). This correlation was not statistically significant (Table 4.3 and Figure 4.2).

Buckwheat prefers sandy soils that drain well, and clayey soil type can cause lodging. According to the texture, or soil particles, analysis, there was a relationship between sand content (\%) and biomass weight. Soil from USDA station had the lowest sand content $(75 \%)$ and gave poor result for the buckwheat growth. According to statistical analysis, this relationship was of marginal significance, Table 4.3 and Figure 4.3.

As stated before, buckwheat does tolerate soil types with wide range of $\mathrm{pH}$ and it grows better in slightly acidic soils ( $\mathrm{pH}$ around 6 and 5.5) but the upper $\mathrm{pH}$ limit is not mentioned in the literature. The present study showed that the best result was obtained from the Tree Tops Park soil with $\mathrm{pH}=6.68$. The soils with the $\mathrm{pH}$ higher or around 8.3 
did not support the gain in biomass: $0.2933 \mathrm{~g}$ (TT Park) versus $0.1233 \mathrm{~g}$ and $0.100 \mathrm{~g}$ (USDA station and Organic garden, Plot 2). Soil from the Organic garden, Plot 1 and Plot 2, had all the same characteristics except $\mathrm{pH}$. Thus, $\mathrm{pH}$ was the only variable responsible for the observed effects on buckwheat growth. The Plot 1 with lower $\mathrm{pH}$ (8.02) gave biomass weight per a dry plant in $0.2283 \mathrm{~g}$, while the Plot 2 with the higher $\mathrm{pH}(8.34)$ gave biomass weight per a dry plant in $0.100 \mathrm{~g}$. Taking into account the fact that $\mathrm{pH}$ scale is logarithmic, the $\mathrm{pH}$ difference in 0.3 can make a noticeable impact on plant growth and development. Statistically this relationship was found to be significant, a negative Pearson coefficient showed that with increasing $\mathrm{pH}$ the plant biomass tended to decrease. Approximately $43 \%$ of the variance of the biomass weight was accounted for by its linear relationship with $\mathrm{pH}$ (Table 4.3 and Figure 4.4).

\subsection{Conclusion}

On the basis of the experimental results, buckwheat found to be capable of growing in a wide range of soil types. It does not need high organic content and can tolerate soils that are relatively poor in the nutrient content. Preferable soil types are those that have $\mathrm{pH}$ less than 8.3 and sandy texture (more than $75 \%$ of sand). Soil $\mathrm{pH}$ appears to be the major limiting factor for buckwheat growth in Florida because limestone soils are alkaline. Sustained application of manure or compost may help in lowering the limestone soil $\mathrm{pH}$. 


\section{CHAPTER 5}

\section{SPATIAL ANALYSIS OF BUCKWHEAT FOR POTENTIAL USE AS A COVER CROP IN FLORIDA FARMS}

\subsection{Introduction}

As stated in the Chapter 1, Fagopyrum esculentum plants were found to be growing naturally in some of the Florida counties (Wunderlin \& Hansen, 2008). Even though buckwheat is not commonly grown in Florida's subtropical zone, researchers from the University of Florida have studied its best planting dates (in Citra, Fl) and suggested to grow it as a cover crop in Florida in late spring and mid-fall to avoid low temperatures (Treadwell \& Huang, 2008; Huang 2009).

In growing buckwheat, the key is to avoid frost because early frost can kill this crop. Temperature range for germination and growth is $45-104^{\circ} \mathrm{F}$ (Treadwell \& Huang, 2008). Usually it germinates in 3-4 days and blooms in 3-4 weeks after planting (Zepp et al., 1996).

The objective of the present chapter was to analyze temperature limitations in Florida for growing buckwheat as a cover crop. It was designed to find which counties in Florida have temperature limitations for the buckwheat growth throughout the year.

\subsection{Materials and Methods}

Spatial analysis, utilizing ArcGIS, was performed to find temperature limitations for the buckwheat growth in Florida throughout the year.

Utilizing the agriculture land data from the Florida Fish and Wildlife Research Institute's website and the temperature data from the 'Spatial Sci' website, the analysis was performed on the average monthly temperature fields that were produced by the 
Inverse Distance Weighted interpolation method for twelve months in Florida. Temperature $60^{\circ} \mathrm{F}$ was set as a critical average monthly value. Below this temperature is not favorable for buckwheat's growth. Two classes were made: below $60^{\circ} \mathrm{F}$, assigned as ' 0 ', and higher $60^{\circ} \mathrm{F}$, assigned as ' 1 '. The temperature limitations were obtained only for three winter months. Agriculture land was presented by two rasterized layers that do not overlap each other. Rasters' cells that present farmland were given a score of ' 1 ' and 'NoData' cells - a score of ' 0 '. The Boolean rasters for December, January, and February temperature classes and the Boolean rasters for agriculture land were multiplied using formula ' $\mathrm{Ag} 1 * \mathrm{~T}+\mathrm{Ag} 2 * \mathrm{~T}$ ' in the raster calculator. A series of maps for these winter months were produced, and names of counties that could have winter temperature limitations for buckwheat planting were found.

\subsection{Results}

The temperature limitations were obtained only for three winter months and only for the central and northern part of the State of Florida. The final maps (Figure 5.1) represent agricultural areas only in those counties where buckwheat can be grown in December, January, and February. Thus, because of possible night frosts, this plant should not be grown in the counties on the north from Citrus, Sumter, Lake, and Volusia in December. For January buckwheat should not be grown in the counties on the north from Hillsborough, Polk, Osceola, and Brevard; and for February - on the north from Hernando, Sumter, Lake, and Seminole. For the rest of the year (from March to November) buckwheat could be grown in any county in the State of Florida. The list of counties is given in Table 5.1 . 
Table 5.1. Florida counties where buckwheat should not be grown in January, February, and December (indicated with ' $\mathrm{x}$ ') because of low winter temperatures.

\begin{tabular}{|c|c|c|c|c|}
\hline No. & County & January & February & December \\
\hline 1 & Alachua & $\mathrm{x}$ & $\mathrm{x}$ & $\mathrm{x}$ \\
\hline 2 & Baker & $\mathrm{x}$ & $\mathrm{x}$ & $\mathrm{x}$ \\
\hline 3 & Bay & $\mathrm{x}$ & $\mathrm{x}$ & $\mathrm{x}$ \\
\hline 4 & Bradford & $\mathrm{x}$ & $\mathrm{x}$ & $\mathrm{x}$ \\
\hline 5 & Brevard (North) & $\mathrm{x}$ & & \\
\hline 6 & Calhoun & $\mathrm{x}$ & $\mathrm{x}$ & $\mathrm{x}$ \\
\hline 7 & Citrus & $\mathrm{x}$ & $\mathrm{x}$ & \\
\hline 8 & Clay & $\mathrm{x}$ & $\mathrm{x}$ & $\mathrm{x}$ \\
\hline 9 & Columbia & $\mathrm{x}$ & $\mathrm{x}$ & $\mathrm{x}$ \\
\hline 10 & Dixie & $\mathrm{x}$ & $\mathrm{x}$ & $\mathrm{x}$ \\
\hline 11 & Duval & $\mathrm{x}$ & $\mathrm{x}$ & $\mathrm{x}$ \\
\hline 12 & Escambia & $\mathrm{x}$ & $\mathrm{x}$ & $\mathrm{x}$ \\
\hline 13 & Flagler & $\mathrm{x}$ & $\mathrm{x}$ & $\mathrm{x}$ \\
\hline 14 & Franklin & $\mathrm{x}$ & $\mathrm{x}$ & $\mathrm{x}$ \\
\hline 15 & Gadsden & $\mathrm{x}$ & $\mathrm{x}$ & $\mathrm{x}$ \\
\hline 16 & Gilchrist & $\mathrm{x}$ & $\mathrm{x}$ & $\mathrm{x}$ \\
\hline 17 & Gulf & $\mathrm{x}$ & $\mathrm{x}$ & $\mathrm{x}$ \\
\hline 18 & Hamilton & $\mathrm{x}$ & $\mathrm{x}$ & $\mathrm{x}$ \\
\hline 19 & Hernando & $\mathrm{x}$ & & \\
\hline 20 & Hillsborough (North) & $\mathrm{x}$ & & \\
\hline 21 & Holmes & $\mathrm{x}$ & $\mathrm{x}$ & $\mathrm{x}$ \\
\hline 22 & Jackson & $\mathrm{x}$ & $\mathrm{x}$ & $\mathrm{x}$ \\
\hline 23 & Jefferson & $\mathrm{x}$ & $\mathrm{x}$ & $\mathrm{x}$ \\
\hline 24 & Lafayette & $\mathrm{x}$ & $\mathrm{x}$ & $\mathrm{x}$ \\
\hline 25 & Lake & $\mathrm{x}$ & & \\
\hline 26 & Leon & $\mathrm{x}$ & $\mathrm{x}$ & $\mathrm{x}$ \\
\hline 27 & Levy & $\mathrm{x}$ & $\mathrm{x}$ & $\mathrm{x}$ \\
\hline 28 & Liberty & $\mathrm{x}$ & $\mathrm{x}$ & $\mathrm{x}$ \\
\hline 29 & Madison & $\mathrm{x}$ & $\mathrm{x}$ & $\mathrm{x}$ \\
\hline 30 & Marion & $\mathrm{x}$ & $\mathrm{x}$ & $\mathrm{x}$ \\
\hline 31 & Nassau & $\mathrm{x}$ & $\mathrm{x}$ & $\mathrm{x}$ \\
\hline 32 & Okaloosa & $\mathrm{x}$ & $\mathrm{x}$ & $\mathrm{x}$ \\
\hline 33 & Orange & $\mathrm{x}$ & & \\
\hline 34 & Osceola (North) & $\mathrm{x}$ & & \\
\hline 35 & Pasco & $\mathrm{x}$ & & \\
\hline
\end{tabular}


Table 5.1 (Continued). Florida counties where buckwheat should not be grown in January, February, and December (indicated with ' $x$ ') because of low winter temperatures.

\begin{tabular}{|l|l|l|l|l|}
\hline 36 & Pinellas & x & & \\
\hline 37 & Polk (North) & x & & \\
\hline 38 & Putnam & x & x & x \\
\hline 39 & Santa Rosa & x & x & x \\
\hline 40 & Seminole & x & & \\
\hline 41 & St. Johns & x & x & x \\
\hline 42 & Sumter & x & & \\
\hline 43 & Suwannee & x & x & x \\
\hline 44 & Taylor & x & x & x \\
\hline 45 & Union & x & x & x \\
\hline 46 & Volusia & x & x & \\
\hline 47 & Wakulla & x & x & x \\
\hline 48 & Walton & x & x & x \\
\hline 49 & Washington & x & x & x \\
\hline
\end{tabular}

\subsection{Discussion}

As the results indicate, there are temperature limitations for winter months in some central and northern counties of the State of Florida. In South Florida and some central counties it could be grown throughout the year (Figure 5.1).

There were some limitations to the performed analysis. The temperature data file contained observations only for 13 weather stations in the State of Florida. Interpolation method allowed to create continuous temperature fields but the output could not be regarded as very accurate because of variations throughout the terrestrial microclimatic zones and because of temperature oscillations from a year to year. Thus, results could be considered as approximate and the climatic variations and microclimate differences on land should be taken into account. The Everglades agricultural area was not included into the analysis. 


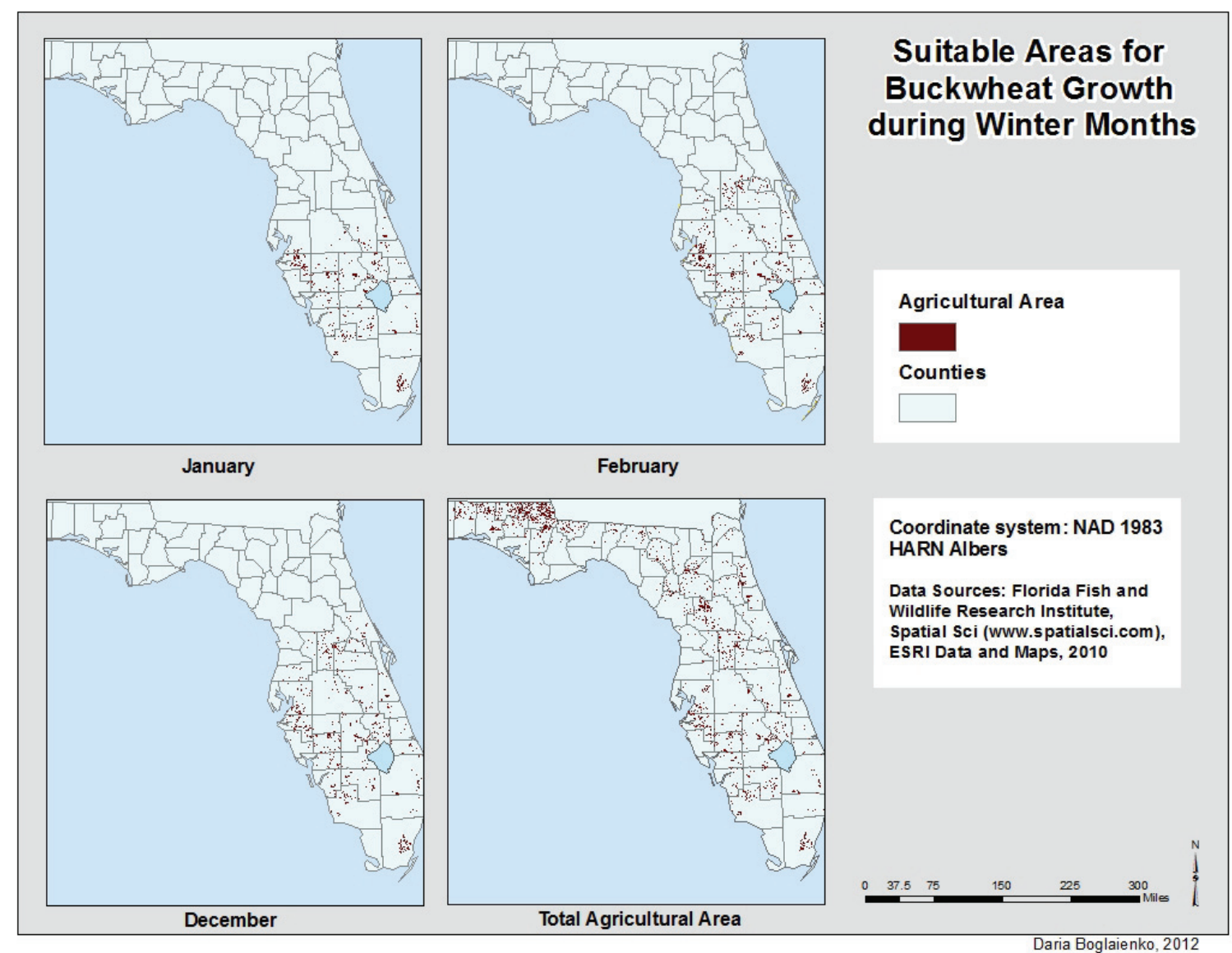

Figure 5.1. Spatial analysis of the temperature regime for buckwheat growth in winter.

\subsection{Conclusion}

Temperature, the main climatic factor limiting the growth of buckwheat in Florida, was analyzed. Spatial analysis, utilizing ArcGIS, showed areas (counties) in the State of Florida, where buckwheat cannot be grown in January, February, and December. However, in South Florida and some parts of Central Florida it can be used as a cover crop during the whole year. 


\section{CHAPTER 6 \\ ECONOMIC ASSESSMENT}

\subsection{Introduction}

This chapter presents the economical assessment of some of the direct benefits that a farmer can derive from growing buckwheat as a cover crop. In this case, the benefits arise from the addition of available phosphorus and potassium into soil, weed suppression, and honey production. Buckwheat is appreciated by beekeepers as a honey crop because the nutrition value of buckwheat honey is very high (Gheldof et al., 2002; Boland, 2013) and because it flowers for a long time, at least for a month (English, 2011). Estimation of external, or long-term, benefits that buckwheat brings to agricultural ecosystems is beyond the scope of this study, but certain indirect benefits are identified. The objective is to investigate whether buckwheat is a profitable choice for a farmer or not.

\subsection{Methodology}

Economic assessment of buckwheat as a cover crop is made using the cost-benefit analysis framework. In general, it could be defined as:

$$
E=E_{\text {benefits }}-E_{\text {costs }}
$$

Where $E$ is net profit in $\$ /$ acre, $E_{\text {benefits }}$ is total direct return in $\$ /$ acre, and $E_{\text {costs }}$ are total coasts of production in $\$ /$ acre.

The costs of buckwheat cover crop include seeds cost $\left(E_{S}\right)$, establishment cost $\left(E_{E}\right)$, and field operation costs $\left(E_{F O}\right)$, which consist of costs of stalk chopper $\left(E_{F O 1}\right)$ and rotary hoe $\left(E_{\mathrm{FO} 2}\right)$ operation:

$$
E_{\text {costs }}=E_{S}+E_{E}+E_{F O 1}+E_{F O 2}
$$


Possible benefits from utilizing a cover crop on a farm could be divided into two groups: short-term and long-term benefits (Stute, 2010). Short-term benefits are those benefits that a farmer gets as direct income or cost savings, for example, weed suppression or added nitrogen for a following crop. Long-term benefits are those that could be defined as public goods or external effects, for example, erosion control or carbon sequestration.

Therefore, short-term benefits for a farmer are the following: cost-share funding $\left(E_{C S}\right)$, weed control $\left(E_{W}\right)$, and fertilizer replacement value for phosphorus $\left(E_{P}\right)$ and for $\operatorname{potassium}\left(E_{K}\right)$ :

$$
E_{\text {benefits }}=E_{C S}+E_{W}+E_{P}+E_{K} .
$$

According to the literature review (Chapter 1) and SARE Handbook ratings of cover crops (Clark, 2007), buckwheat is a poor nitrogen scavenger, and that is why the benefit from nitrogen fertilizer savings is not included. Significant enrichment of the soil with total nitrogen that the current study presents (Chapter 3, Table 3.1) requires an additional research.

Long term or external benefits would also include diversification of ecosystem (attraction of honey bees and other native pollinators), and prevented water treatment costs from excess of phosphorus fertilizer that gets into the surface water bodies and riches groundwater through runoff and rainwater (Tegtmeier \& Duffy, 2004). In comparison with some other cover crops, such as rye, oats and barley, buckwheat does not provide a lot of biomass. For instance, buckwheat produces $2000-4000 \mathrm{lb}$ of biomass per acre while rye, oats, and barley produce $3000-10000 \mathrm{lb}$ per acre. Therefore, carbon sequestration is not among the main external benefits (Clark, 2007). 
In case that a farmer has a bee yard, the benefits would include income from honey production $\left(E_{H}\right)$. Thus, the total per acre benefit will be:

$$
E_{\text {benefits }}^{H}=E_{C S}+E_{W}+E_{P}+E_{K}+E_{H} .
$$

The following analysis is made for two cases of short-term benefits: for a farmer with honey production facilities $\left(E^{H}\right)$ and without such facilities. The assessment of external or long-term benefits is not included in this analysis.

\subsection{Calculations}

All calculations are made for one acre of a farmland.

The cost of buckwheat seeds per acre $\left(E_{S}\right)$ is found by multiplying the unit market price of seed by planting rate (lb/acre). The lowest current price is $\$ 38 / 50 \mathrm{lb}$ (Buckwheat marketing, 2013). As recommended by the researchers at the Cornell University's Agricultural Experiment Station, $70 \mathrm{lb} / \mathrm{acre}$ is the seeding rate for buckwheat as a cover crop (Bjorkman et. al., 2008).

$$
E_{S}=(\$ 38 \cdot 70 \mathrm{lb} / \mathrm{acre}) / 50 \mathrm{lb}=\$ 53.2 \text { /acre }
$$

According to Brian P. Jones, the establishment cost $\left(E_{E}\right)$ is $\$ 15.86$ per acre (Jones, 2009). Stalk chopper $\left(E_{F O I}\right)$ is $\$ 9.40$ and rotary hoe $\left(E_{F O 2}\right)$ is $\$ 8.40$ per acre (NASS Custom Rate Guide, 2007).

Thus,

$$
E_{\text {costs }}=53.2+15.86+9.40+8.40=\$ 86.86 \text { /acre. }
$$

The USDA Environmental Quality Incentive Program provides incentives for a farmer who grows a cover crop. The cover crop cost-share reimbursement is $\$ 25 /$ acre for the Program year 2013 (BMP Summary, 2013). Thus, $E_{C S}=\$ 25$ /acre. 
Buckwheat has an excellent score in the 'weed fighter' rating (Clark, 2007) so that the following crop may not need any herbicides applications. The estimate of prevented costs of herbicide use is obtained from a study done in California (Klonsky and Mitchell, 2004). The researchers compared standard and conservation tillage systems costs for tomatoes and cotton grown without and with cover crop. The average savings in herbicide operations for tomatoes and cotton in this study are 23 and 14 (\$/acre respectively). The average of these two numbers is taken for a given analysis. Hence, $E_{W}$ $=\$ 18.5$ /acre.

The following steps show the estimation of savings on fertilizer use. The concentrations of available phosphorus, total potassium and nitrogen are taken as a difference of the macronutrients' concentrations in analyzed soil samples before and after planting and incorporating buckwheat.

The average increase in available phosphorus (AP) is $45.6 \mathrm{ppm}$ or $45.6 \mathrm{mg} / \mathrm{kg}$ (Chapter 3, Table 3.2). Thus, one unit of soil, or $1 \mathrm{~kg}$ of soil, has $45.6 \mathrm{mg}$ of AP. The average bulk density of soil is $0.57 \mathrm{~g} / \mathrm{cm}^{3}$ (Chapter 3, Table 3.1). Volume of one $\mathrm{kg}$ of soil is:

$$
V=10^{3} \mathrm{~g} / 0.57 \mathrm{~g} / \mathrm{cm}^{3}=1754 \mathrm{~cm}^{3} .
$$

Given the fact that analyzed soil samples were taken from 0 to $15 \mathrm{~cm}$ in depth, the surface of one unit of soil is

$$
S=V / 15 \mathrm{~cm}=1754 \mathrm{~cm}^{3} / 15 \mathrm{~cm}=116.93 \mathrm{~cm}^{2}=0.0117 \mathrm{~m}^{2} .
$$

The analysis is performed for an acre of a land. Knowing that a square meter is equal to $2.4710^{-4}$ acre, the surface of one unit of soil is $2.9810^{-6}$ acre. The total increase in $\mathrm{AP}$ concentration $\left(C_{P}\right)$ per acre is given by, 


$$
C_{P}=45.6 \mathrm{mg} / 2.8910^{-6} \text { acre }=15.7810^{6} \mathrm{mg} / \text { acre }=15.78 \mathrm{~kg} / \text { acre } .
$$

The commonly used phosphorus fertilizer, triple super phosphate, contains $46 \%$ of phosphate and $20 \%$ of phosphorus (NRES, 2010). The amount of the fertilizer that is equivalent to the estimated concentration of the increased AP is $15.78 / 0.2=78.9 \mathrm{~kg} / \mathrm{acre}$ or $173.9 \mathrm{lb} / \mathrm{acre}$.

The average farm price of super phosphate is $\$ 665 /$ ton (Agricultural Prices, 2012). Therefore, saved cost of phosphorus fertilizer is:

$$
E_{P}{ }_{P}=78.9 \mathrm{~kg} / \text { acre } \cdot \$ 665 / 1000=\$ 52.5 / \text { acre. }
$$

The cost of fertilizer application is $\$ 4.95$ /acre (Iowa Farm Custom, 2013).

$$
E_{P}=52.5+4.95=\$ 57.45 \text { /acre. }
$$

The first two steps stay the same for the potassium analysis. The average increase in potassium in soil after utilizing buckwheat is $57.2 \mathrm{ppm}$ or $57.2 \mathrm{mg} / \mathrm{kg}$ (Chapter 3, Table 3.2). One acre of a farm would have:

$$
C_{K}=57.2 \mathrm{mg} / 2.8910^{-6} \text { acre }=19.7910^{6} \mathrm{mg} / \mathrm{acre}=19.79 \mathrm{~kg} / \mathrm{acre} .
$$

Potassium chloride fertilizer has $60 \%$ of potassium. To substitute the amount of potassium, $C_{K}$, which buckwheat residues added to soil, a farmer would need $19.79 / 0.6$ $=32.98 \mathrm{~kg} /$ acre or $72.71 \mathrm{lb} /$ acre.

The average farm price of potassium chloride is $\$ 647$ /ton (Agricultural Prices, 2012). Saved cost of potassium fertilizer is:

$$
E^{\prime}{ }_{K}=32.98 \mathrm{~kg} / \mathrm{acre} \cdot \$ 647 / 1000=\$ 21.34 \text { /acre. }
$$

With the cost for a fertilizer application:

$$
E_{K}=21.34+4.95=\$ 26.29 \text { /acre }
$$


An acre of flowering buckwheat provides nectar that is enough to produce 100$150 \mathrm{lb}$ of honey (English, 2001; Myers \& Meinke, 1994). If buckwheat is grown as a cover crop, the flowering period would be shorter and the honey production could be $150 \mathrm{lb} / 12=12.5 \mathrm{lb}$. The least price found for buckwheat honey is $\$ 4.17 / \mathrm{lb}$ (Nature's Finest, 2011). The average income from one acre would be $\$ 4.17 / \mathrm{lb}$ x $12.5 \mathrm{lb}=\$ 52.13$.

Short-term benefits for a farmer not considering honey production are:

$$
E_{\text {benefits }}=25+18.5+57.45+26.29=\$ 127.24 \text { /acre. }
$$

Short-term benefits for a farmer with bee hives are:

$$
E_{\text {benefits }}^{H}=25+18.5+57.45+26.29+52.13=\$ 179.37 \text { /acre. }
$$

Total income for a farmer without bee yard after subtracting all costs would be:

$$
E=127.24-86.86=\$ 40.38 \text { /acre }
$$

Total income for a farmer with bee hives:

$$
E^{H}=179.37-86.86=\$ 92.51 \text { /acre } .
$$

In case when a farmer does not have honey production facilities the benefit from buckwheat as a nectar providing plant would appear as a public good for all beekeepers in a neighborhood. Table 6.1 summarizes calculated benefits and costs, as well as net benefits for a farmer and for a farmer-beekeeper. 
Table 6.1. Cost-benefit analysis of buckwheat as a cover crop.

\begin{tabular}{|l|l|l|l|}
\hline \multicolumn{2}{|c|}{ Benefits, $\$$ acre } & \multicolumn{2}{c|}{ Costs, $/$ acre } \\
\hline $\begin{array}{l}\text { Cost-share funding, } \\
E_{C S}\end{array}$ & 25.00 & Seeds, $E_{S}$ & 53.2 \\
\hline Weed control, $E_{W}$ & 18.50 & Establishment, $E_{E}$ & 15.86 \\
\hline $\begin{array}{l}\text { Phosphorus fertilizer } \\
\text { replacement, } E_{P}\end{array}$ & 57.45 & $\begin{array}{l}\text { Field operation, } E_{F O}: \\
\text { Stalk chopper, } E_{F O 1}\end{array}$ & 9.40 \\
\hline $\begin{array}{l}\text { Potassium fertilizer } \\
\text { replacement, } E_{K}\end{array}$ & 26.29 & Rotary hoe, $E_{F O 2}$ & 8.40 \\
\hline Total, $E_{\text {benefits }}$ & 127.24 & Total, $E_{\text {costs }}$ & 86.86 \\
\hline \multicolumn{4}{|l|}{ Net Benefit $E=40.38$} \\
\hline Honey, $E_{H}$ & 52.13 & Total, $E_{\text {costs }}$ \\
\hline Total, $E_{\text {benefits }}^{H}$ & 179.37 & 86.86 \\
\hline \multicolumn{4}{|l|}{ Nenefit $E^{H}=92.51$} \\
\hline
\end{tabular}

\subsection{Discussion}

As the results show, buckwheat is a profitable cover crop. In case when a farmer does not have a bee yard and the provided nectar is a public good for neighbor lands, the choice to plant buckwheat as a cover crop is economically reasonable. For example, if a half of a farm is planted to a cover crop, then the net benefit for an average farm size in Florida, which is 195 acres, (Florida Department of Agriculture, n.d.) would be around 4,000 dollars.

The above analysis cannot be considered as the complete estimate of all shortterm benefits. Buckwheat abilities to mellow soil by decreasing its bulk density, to suppress pathogenic microflora (Bjorkman, 2009), and to attract some other native insects (Treadwell \& Huang, 2008) are not included into given assessment. It does not comprise calculations for the long-term benefits and externalities for a wild-life diversification and eutrophication prevention. 
The assessment of phosphorus and potassium fertilizers savings is built on results from the soil analysis tests that were made for Chapter 3. Therefore, the field level economic comparison of buckwheat with other cover crops, such as winter rye or oats, is not feasible. For this goal, additional research would be needed.

\subsection{Conclusion}

The income that buckwheat provides as a cover crop is higher than the total costs of seeds and cultural practices. In addition to savings that a farmer has from applying less phosphorus and potassium, and from not applying weed control in a filed for a crop grown after buckwheat, there could be also income from buckwheat as a nectar source. In the case that a farmer has beekeeping facilities the net benefit could be $\$ 92.51$ per acre; in the case a farmer does not have bee hives, the net benefit could be $\$ 40.38$ per acre. 


\section{CHAPTER 7}

\section{CONCLUSION}

Buckwheat as a cover crop promotes biodiversity; the value of the ecosystem services this creates is of considerable importance in a sustainable agroecosystem. On the basis of the results from this thesis research buckwheat does have a potential to be utilized as a cover crop in Florida. In the northern and some central parts of Florida it could be too cold to grow it during the winter months but in South Florida it could be planted throughout the year. During the experimental study it was observed that buckwheat, when planted in the late fall, showed very rapid germination, growth, and residue decomposition. Flowering began four weeks after the planting date and continued till the plants were terminated, attracting pollinators. Buckwheat did not require pesticides and did not have any diseases. Planted densely in rows $15 \mathrm{~cm}$ apart, it shaded soil quickly, thus, showing its ability to outcompete weeds.

After the residues were decomposed, soil samples were analyzed for the physicochemical characteristics and compared with the soil samples taken for the analysis before buckwheat was planted. The results indicated that following the buckwheat cover crop, soil $\mathrm{pH}$ and bulk density slightly decreased, and nitrogen and available phosphorus concentrations significantly increased. Buckwheat was found to be a good phosphorus scavenger allowing for farmers to save on phosphorus fertilizer use for the following cash crop. Although not reported extensively in the literature, buckwheat does appear to contribute to biological nitrogen fixation, and the results showed that nitrogen concentration in soil increased significantly. The mechanism might be attributed to buckwheat root exudates that are good carbon and energy source for the nitrogen fixing 
bacteria in the soil. Potassium, magnesium and calcium were absorbed from the deeper soil layer and moved up with the plants residues that resulted in increased concentrations of those elements in the top soil.

Additional experiments showed that buckwheat can grow successfully in soil that is poor in organic matter. Soil that has sandy texture is more preferable, but soil that is alkaline (pH higher than 8.3) can suppress buckwheat's growth. Soil that has mycorrhizal fungi spores can lead to colonization of buckwheat roots by AMF. Hence, it could be used in the crop rotations before a mycorrhizal host cash crop without affecting the benefits of AMF symbiosis.

As the results show, buckwheat benefits from the AMF symbiosis in terms of higher biomass production but its height, leaf area development, and root:shoot ratio are not affected. Arbuscular mycorrhizal fungi show a positive effect on buckwheat phosphorus uptake when the soil source is inorganic phosphorus, but not when the source is organic phosphorus.

Additional research regarding the role of buckwheat root exudates on biological nitrogen fixation, phosphorus uptake and mellowing of soil is needed.

Lastly, from the economic point of view, buckwheat is a profitable cover crop. The main part of the income that it can provide to a farmer comes from the savings on phosphorus fertilizer and honey production. In case the farmer does not have a bee hive, the income from the enrichment of soil with phosphorus and potassium, and weed suppression could be around $\$ 40$ per acre. External benefits, such as diversification of ecosystem (attraction of honey bees and other native pollinators), and prevented water 
treatment costs from excess phosphorus fertilizer that gets into the surface water bodies and riches groundwater through runoff, were not estimated.

In the US buckwheat is mainly grown in the northern states for the grain production. Even though, for some cultural reasons, it is not popular as a food source among the American people and goes for the export, it could be grown as a cover crop more widely, including Florida, adding significant value to the agroecosystems and remaining profitable for farmers. 


\section{REFERENCES}

Agricultural Prices. 2012. Retrieved from USDA NASS: http://www.ers.usda.gov/dataproducts/fertilizer-use-and-price.aspx\#.UVyIIrTYB8F

Amann, C. and Amberger, A. 1989. Phosphorus efficiency of buckwheat (Fagopurum esculentum). Journal of Plant Nutrition and Soil Science, 152(2), 181-189.

Anderson, D. M., Glibert, P. M., and Burkholder J. M. 2002. Harmful algal blooms and eutrophication: nutrient sources, composition, and consequences. Estuaries, 25 (4b), 704726.

BMP Summary. 2013. Cover crops. Retrieved April 3, 2013:

http://www.dcr.virginia.gov/stormwater_management/documents/cmw/wpcovercrop.pdf

Bjorkman, T. 2009. Information for buckwheat growers. N.Y. State Agricultural Experiment Station, Cornell Univ. Retrieved August 25, 2012:

http://www.hort.cornell.edu/bjorkman/lab/buck/guide/whygrow.php

Bjorkman, T., Bellinder, R., Hahn, R., and Shail, W. J. 2008. Buckwheat cover crop handbook, Cornell Univ. Retrieved April 3, 2013:

www.sare.org/.../Buckwheat\%20Cover\%20Crop\%20Handbook.pdf

Boland, M. 2013. Buckwheat profile. Retrieved from Ag MRC:

http://www.agmrc.org/commodities_products/specialty_crops/buckwheat_profile.cfm

Buckwheat. 2011. Retrieved from Grains and Legumes Nutrition Council:

http://www.glnc.org.au/grains/types-of-grains/buckwheat

Buckwheat: a versatile short-season crop. n.d. Retrieved from Thomas Jefferson Agricultural Institute:

http://www.jeffersoninstitute.org/pubs/buckwheat.shtml\#Harvest\%20and\%20Storage

Buckwheat Marketing. 2013. Retrieved from Homestead organics: http://www.homesteadorganics.ca/buckwheat-marketing.aspx

Callaway, R. M., Marler, M. J., and Zabinski, C. A. 1999. Mycorrhizae indirectly enhance competitive effects of an invasive forb on a native bunchgrass. Ecology, 80(4), 1180 .

Chen, R. F., Shen, R. F., Yang, X. D., and Wang, X. 2010. Effects of buckwheat growth on variation of aluminum and major metals in root-zone soil solutions. Journal of Plant Nutrition and Soil Science, 173, 788-794. 
Chen, Q. 2001. Discussion on the origin of cultivated buckwheat in genus Fagopyrum (Polygonaceae). The proceeding of the $8^{\text {th }}$ ISB, 206-213. Retrieved August 25, 2012 http://nmcp.mf.uni-lj.si/Fago/SYMPO/2001sympoEach/2001s-206.pdf

Clark A. 2007. Managing Cover Crops Profitably. $3^{\text {rd }}$ Ed. SARE Handbook Series book 9. Retrieved from: http://www.sare.org/Learning-Center/Books/Managing-Cover-CropsProfitably-3rd-Edition

Dovzhenko, L. 2010. Buckwheat. (In Russian). Retrieved February 21, 2013: http://www.vitusltd.ru/med_grechka.html

English, J. 2001. Buckwheat fills that empty spot. Retrieved from Maine organic farmers and gardeners association:

http://www.mofga.org/Publications/MaineOrganicFarmerGardener/Summer2001/Buckw heat/tabid/1701/Default.aspx

FAOSTAT. 2010. Retrieved August 28, 2012 http://faostat.fao.org/site/339/default.aspx

Florida Department of Agriculture and Consumer Services. n.d. Retrieved April 4, 2013: http://florida-agriculture.com/consumers/crops/agoverview/

Gheldof, N., Wang, X., and Engeseth, N. 2002. Identification and quantification of antioxidant components of honeys from various floral sources. Journal of Agricultural and food chemistry 50, 5870-5877.

Gliessman, S. R. 2006. Agroecology: the ecology of sustainable food systems. $2^{\text {nd }}$ ed. Boca Raton, FL: CRC Press, Taylor \& Francis Group.

Gosling, P., Hodge, A., Goodlass, G., and Bending, G. D. 2006. Arbuscular mycorrhizal fungi and organic farming. Agriculture, Ecosystems and Environment, 113, 17-35.

Habte, M., and Osorio, N. W. 2001. Arbuscular Mycorrhizas: producing and applying arbuscular mycorrhizal inoculum. Honolulu (HI): University of Hawaii. 47 p. Retrieved April 14, 2013:

http://scholarspace.manoa.hawaii.edu/bitstream/handle/10125/25589/amf_manual.pdf?se quence $=1$

Heijden, M.G.A. and Sanders, I.R. (eds.). 2002. Mycorrhizal Ecology. Ecological Studies, Vol. 157. Berlin, Heidelberg: Springer-Verlag.

Huang, P. 2009. Optimizing buckwheat use as a weed suppressive cover crop for sustainable cropping systems in Florida. Final report: graduate student project. University of Florida. Retrieved from SARE:

http://mysare.sare.org/mySARE/ProjectReport.aspx?do=viewRept\&pn=GS07$057 \& y=2009 \& t=1$ 
Ikeda, S., Yamashita, Y., Tomura, K., and Kreft, I. 2006. Nutritional comparison in mineral characteristics between buckweet and cereals. Fagopurum, 23, 61-65.

Iowa Farm Custom Rate Survey. 2013. Retrieved April 3, 3013:

https://www.extension.iastate.edu/publications/FM1698.pdf

Irving, W. 2012. The legend of sleepy hollow (1820). Book. Along About Midnight. Retrieved April 29, 2013:

http://www.alongaboutmidnight.com/study/IRVING/W/THELEGENDOFSLEEPYHOL LOW/THELEGENDOFSLEEPYHOLLOW.NE.pdf

Jones, B. P. 2009. The economic value of cover crops to Shenandoah valley producers. Shenandoah Valley Extension Agronomist. October 2009. Retrieved April 3, 2013: http://ebookbrowse.com/the-economic-value-of-cover-crops-to-shenandoah-valleyproducers-pdf-d183330506

Karasawa, T., Kasahara, Y., and Takebe, M. 2002. Differences in growth responses of maize to preceding cropping caused by fluctuation in the population of indigenous arbuscular mycorrhizal fungi. Soil Biol.Biochem. 34, 851-857.

Kessler, M., Jonas, R., Strasberg, D., and Lehnert, M. 2010. Mycorrhizal colonizations of ferns and lycophytes on the island of La Reunion in relation to nutrient availability. Basic and Applied Ecology, 11, 329-336.

Klonsky, K. and Mitchell, J. 2004. Economic performance of conservation tillage for cotton and tomato production in California. Retrieved April 3, 2013: http://ageconsearch.umn.edu/bitstream/20121/1/sp04k103.pdf

Likar, M., Bukovnik, U., Kreft, I., Chrungoo, N. K., and Regvar, M. 2008. Mycorrhizal status and diversity of fungal endophytes in roots of common buckwheat (Fagopyrum esculentum) and tartary buckwheat (F. tataricum). Mycorrhiza. Sep 18 (6-7), 309-315.

Malceva, N.N., Nadkernichnaya, E.V., and Lokhova V.I. 1987. The buckwheat associative nitrogen fixation. The Ukrainian Research Institute of Agricultural microbiology. Chernigov, USSR. Retrieved April 20, 2013: http://lnmcp.mf.unilj.si/Fago/SYMPO/1989SympoEach/1989s-2-431.pdf

Miller, M.H. 2000. Arbuscular mycorrhizae and the phosphorus nutrition of maize. A review of the Guelph studies. Can. J. Plant Sci. 80, 47-52.

Myers, R., L. and Meinke, L. J. 1994. Buckwheat: a multi-purpose, short-season alternative. University of Missouri Extension. Retrieved April 19, 2013: http://extension.missouri.edu/p/G4306 
NASS Custom Rate Guide. 2007. Retrieved April 3, 2013:

http://www.nass.usda.gov/Statistics_by_State/Wisconsin/Publications/custom_rates_200 7.pdf

Nature's Finest Honey Hill Farms. 2011. Buckwheat honey. Retrieved April 3, 2013: http://www.honeyhillfarmsmn.com/products-page/honey/natures-finest-buckwheathoney-2-lb/

NRES 201. 2010. Phosphorus. Lecture 38. Retrieved April 2, 2013:

http://courses.nres.uiuc.edu/nres201/Lectures/NRES\%20201\%20Phosphorus\%20Handou ts $\% 20 \% 282010 \% 291 . p d f$

Page, A.L. 1982. Methods of soil analysis. Part 2 Chemical and microbiological properties. American Society of Agronomy. Madison, Wisconsin, USA.

Parahin, N.V. 2010. Buckwheat: biological opportunities and the ways of the implementation (In Russian). Vestnik, Orel 4 (10): 4-8.

Poorter, H., Niklas, K.J., Reich, P.B., Oleksyn, J., Poot, P., and Mommer, L. 2012. Biomass allocation to leaves, stems and roots: meta-analyses of interspecific variation and environmental control. New Phytologist, 193, 30-50.

Quettier-Deleu, C., Gressier, B., Vasseur, J., Dine, T., Brunet, C., Luyckx, M., Cazin, M., Cazin, J., Bailleul, F., and Trotin, F. 2000. Phenolic compounds and antioxidant activities of buckwheat (Fagopyrum esculentum Moench) hulls and flour. Journal of Ethnopharmacology 72, 35-42.

Rogers, H. H., Prior, S. A., Runion, G. B., and Mitchell R. J. 1996. Root to shoot ratio of crops as influenced by CO2. Plant and Soil, 187, 229-248.

Ruttenberg, K. C. 2003. The global phosphorus cycle. Treatise on Geochemistry, 8, 585643. Retrieved: September 14, 2012 http://adsabs.harvard.edu/abs/2003TrGeo...8..585R

Sattell, R., Dick, R., Karow, R., and McGrath, D. 1998. Buckwheat. Oregon State University Extension Service. EM 8693. January 1998. Retrieved: January 22, 2013 http://ir.library.oregonstate.edu/xmlui/bitstream/handle/1957/14958/em8693.pdf

Shetty, K. G., Hetrick, B. A. D., and Schwab, A. P. 1995. Effects of mycorrhizae and fertilizer amendments on zinc tolerance of plants. Environmental Pollution, 88(3), 307314.

Smith, S.E. and Read, D.J. 2008. Mycorrhizal symbiosis. Academic Press. Retrieved from University of Sydney: http://bugs.bio.usyd.edu.au/learning/resources/Mycology/Plant_Interactions/Mycorrhizas/ Arbuscular/rootColonisation.shtml 
Stute, J. 2010. Cover Crop Economics. The green behind the green. Rock County UW Extension. Retrieved April 3, 2013: http://fyi.uwex.edu/sustag/files/2013/02/Economicsof-Cover-Crops.pdf

Tamura, H., Honda, M., Sato, T., and Kamachi, H. 2005. Pb hyperaccumulation and tolerance in common buckwheat (Fagopurum esculentum Moench). Journal of Plant Research, 118, 355-359.

Tegtmeier, E. M. and Duffy M. D. 2004. External costs of agricultural production in the United States. International Journal of Agricultural Sustainability, 2(1), 1-20.

Treadwell, D., and Huang, P. 2008. Buckwheat: a cool-season cover crop for Florida vegetable systems. University of Florida, IFAS Extension. Retrieved January 25, 2013: http://edis.ifas.ufl.edu/pdffiles/HS/HS38600.pdf

USDA NASS, Census Program. 2007. Retrieved August 4, 2012:

http://www.quickstats.nass.usda.gov

Vestberg, M., Saari, K., Kukkonen, S., and Hurme, T. 2005. Mycotrophy of crops in rotation and soil amendment with peat influence the abundance and effectiveness of indigenous arbuscular mycorhhizal fungi in field soil. Mycorrhiza, 15, 447-458.

Vierheilig, H., Lerat, S., and Piche, Y. 2003. Systemic inhibition of arbuscular mycorrhiza development by roots exudates of cucumber plants colonized by Glomus mosseae. Mycorrhiza 13, 167-170.

Virant, I., and Kajfez-Bogataj, L. 1988. Vesicular-arbuscular mycorrhiza in buckwheat. Fagopurum, 8, 10-14.

Wang, Y. 2010. Production assessment and strategies development for the buckwheat products in China (In Russian). Vestnik, Orel 4 (10): 9-14.

Wunderlin, R. P., and Hansen, B. F. 2008. Atlas of Florida Vascular Plants. Institute for Systematic Botany, University of South Florida, Tampa. Retrieved from Plant Atlas: http://www.plantatlas.usf.edu

Zepp, G., Harwood, J., Hammond, C., and Somwaru, A. 1996. Buckwheat: an economic assessment of the feasibility of providing multiple-peril crop insurance. Economic Research Service, USDA. 